\title{
Rous-Whipple Award Lecture
}

\section{Peroxisome Proliferators and Peroxisome Proliferator- Activated Receptor $\alpha$}

\section{Biotic and Xenobiotic Sensing}

\author{
Janardan K. Reddy \\ From the Department of Pathology, Northwestern University, \\ Feinberg School of Medicine, Chicago, Illinois
}

The morphological phenomenon of peroxisome (microbody) proliferation, induced in hepatic parenchymal cells of rats and mice by the hypolipidemic drug clofibrate, ${ }^{1}$ fascinated me ever since I ventured into the research laboratory of the late Donald J. Svoboda at the University of Kansas Medical Center as a pathology resident more than 35 years ago. The elegant ultrastructural illustrations of liver cell cytoplasm suffocated with "microbodies" Don Svoboda displayed ${ }^{2}$ left an indelible impression that propelled me to pursue the cellular, biochemical, and molecular underpinnings of that phenomenon of peroxisome proliferation. $^{3-8}$ The central effort of my research since then revolves around the analysis of causes and consequence of the induction of peroxisome proliferation by structurally diverse classes of chemicals, which we designated as peroxisome proliferators. ${ }^{9}$ This longstanding interest and avocation enabled my colleagues and me to make certain factual and conceptual advances, among which the following deserve special mention. First, the demonstration that the phenomenon of peroxisome proliferation can be induced by many structurally diverse agents led to our proposal that peroxisome proliferation is linked to lipid metabolism ${ }^{8,9}$ and this formed the impetus for the identification of the peroxisomal $\beta$-oxidation system. ${ }^{10}$ Second, the consistent observation that peroxisome proliferation induced by peroxisome proliferators is carcinogenic in rats and mice, ${ }^{11-14}$ resulted in the proposal that peroxisome proliferators form a novel class of nonmutagenic chemical carcinogens. ${ }^{15,16}$ This resulted in the dictum that all peroxisome proliferators are potentially hepatocarcinogenic and that peroxisome proliferation can serve as a biological marker or predictor of carcinogenicity of a nongenotoxic chemical. ${ }^{15,17-19}$ Third, sustained disproportionate induction of hydrogen peroxide generating- and hydrogen peroxide-degrading enzymes in livers by peroxisome proliferators resulted in the postulation that hepatocarcinogenicity of peroxisome proliferators is due to oxidative stress leading to oxidative DNA damage from metabolic perturbations. ${ }^{15,19-23}$ Fourth, the tissue/cell specificity of pleiotropic responses and the coordinated rapid transcriptional activation of peroxisomal $\beta$-oxidation system genes led to the hypothesis that peroxisome proliferators exert their action by a receptor-mediated mechanism. ${ }^{15,18,19,24,25}$ This formed the stimulus for the identification of a subfamily of nuclear receptors called peroxisome proliferator-activated receptors (PPARs). ${ }^{26,27}$ PPARs play a central role in regulating the combustion and storage of dietary lipids, essentially by serving as sensors for fatty acids and their metabolic intermediates. In addition, they sense certain classes of exogenous chemicals and, in the process, transcriptionally regulate sets of target genes that control energy (lipid) metabolism. Thus, PPARs function as sensors for both endogenous and exogenous stimuli and this sensing mechanism regulates lipid homeostasis. I summarize here some of our studies dealing with the biological effects of peroxisome proliferators, an area of research we "nurtured" with some proprietary pride for many years. I am greatly honored that this work has been recognized by the Rous-Whipple Award this year, and dedicate this to all those who were part of our efforts and others who contributed to the developments in this field. My purpose in this paper is to review our own studies with inclusion of

Supported in part by U.S. Public Health Service grants GM23750 and CA104578 and by the Joseph L. Mayberry Endowment Fund.

The Rous-Whipple Award was established by the American Society for Investigative Pathology to recognize a career of outstanding scientific contribution. Janardan K. Reddy, the 2003 recipient of the Rous-Whipple Award, delivered a lecture entitled, "Peroxisome Proliferators and Peroxisome Proliferator-Activated Receptor $\alpha$ : Biotic and Xenobiotic Sensing" after accepting the award at the 2003 annual meeting of the American Society for Investigative Pathology in San Diego, California.

Accepted for publication March 2, 2004

Address reprint requests to Janardan K. Reddy, M.D., Department of Pathology, Northwestern University, Feinberg School of Medicine, Chicago, IL 60611. E-mail: jkreddy@northwestern.edu. 


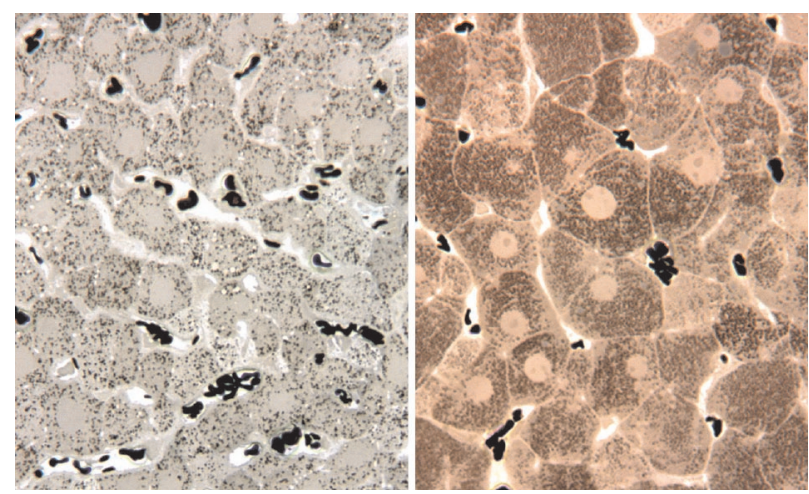

Figure 1. Mouse liver processed for the cytochemical localization of peroxisomal catalase. Brown dots in hepatocyte cytoplasm represent catalase containing peroxisomes. Normal mouse (left); mouse treated with Wy-14, 643 a peroxisome proliferator for 2 weeks (right).

relevant literature citations although they are in no way comprehensive.

\section{Microbody to Peroxisome}

The morphological descriptions of an organelle called "microbody" 28 and biochemical and subcellular fractionation studies that culminated in the "peroxisome" concept $^{29,30}$ originated in the 1950's. Rhodin ${ }^{28}$ first described the presence of a special type of cytoplasmic organelle, characterized by a single membrane and a finely granular matrix, in the proximal convoluted tubule cells of the mouse kidney, which he called "microbody." Subsequently, Rouiller and Bernhard ${ }^{31}$ described the existence in rat liver cells of "microbodies" that also contained a dense core with a regular crystalloid structure. This crystalloid core in liver peroxisomes is formed by urate oxidase. ${ }^{30,32}$ The elegant biochemical studies of De Duve and his co-workers ${ }^{32}$ led to the discovery that $\mathrm{H}_{2} \mathrm{O}_{2}$-generating flavin oxidases coexist with the $\mathrm{H}_{2} \mathrm{O}_{2}$ degrading enzyme, catalase, in the same cellular compartment. Subsequent morphological studies of these cellular fractions provided the unequivocal evidence that this organelle fraction indeed consists of so-called "microbodies." ${ }^{30}$ In 1965, De Duve proposed the name "peroxisome" for this organelle to bring attention to its $\mathrm{H}_{2} \mathrm{O}_{2}$ generation and degradation properties. ${ }^{29}$ Gradually the noncommittal morphological descriptive name "microbody" became a historical relic. Although an earlier assumption was that peroxisomes existed almost exclusively in liver and kidney cells, ${ }^{32}$ and in the protist Tetrahymena pyriformis, ${ }^{33}$ the development, by Novikoff and Goldfischer, ${ }^{34}$ of a cytochemical staining procedure for selectively demonstrating the localization of catalase at the subcellular level, led to the discovery that these organelles are present in virtually all eukaryotic cells. ${ }^{35-37}$ Using this procedure, we established the presence of peroxisomes in Leydig cells and Leydig cell tumors of testis. ${ }^{36,37}$ This technique is routinely used for visual assessment of alterations in peroxisome population density in liver parenchymal cells under a variety of experimental conditions and in disease models (Figures 1 and 2). The subsequent advent of protein A-gold immunocytochem-

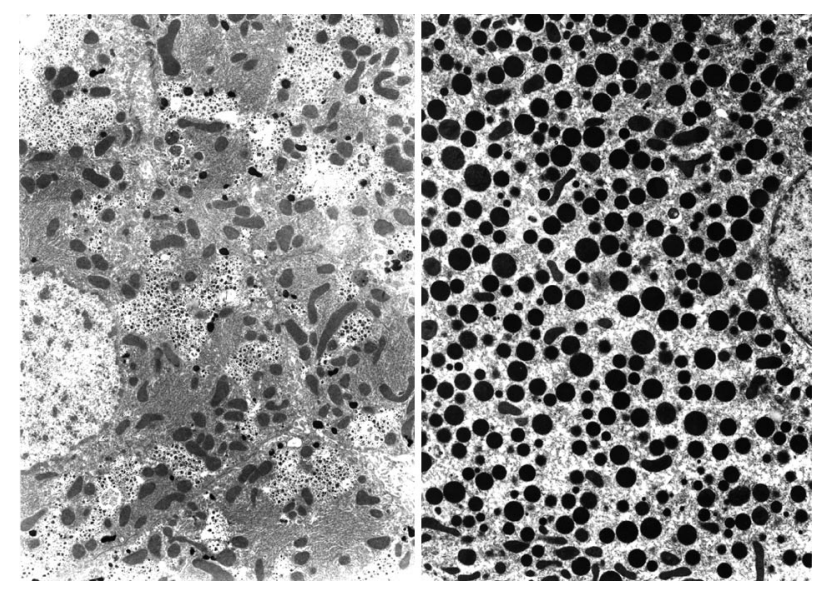

Figure 2. Electron micropgraphs representing normal (left) and $\mathrm{Wy}-14,643$ treated (right) mouse livers cells. Peroxisomes are stained as dark osmiophilic organelles.

ical technique further enabled the visualization of the presence of various proteins in different peroxisomal compartments such as the membrane, matrix, and crystalloid core (Figure 3). Immunocytochemical approaches also permitted evaluation of qualitative and quantitative changes in specific enzymes under a variety of experimental conditions. ${ }^{38}$

Peroxisomes contain more than 60 proteins and perform a variety of biological functions. By virtue of the presence of an array of oxidases, such as urate oxidase, D-amino acid oxidase, L- $\alpha$-hydroxyacid oxidase A and B, polyamine oxidase, glutaryl-CoA oxidase, pipecolic acid oxidase, oxalate oxidase, acyl-CoA oxidase, trihydroxycholestanoyl-CoA oxidase, and pristanoyl-CoA oxidase, ${ }^{39}$ these organelles may be responsible for as much as $20 \%$ of oxygen consumption in liver. ${ }^{32}$ Thus, formation of $\mathrm{H}_{2} \mathrm{O}_{2}$ is one of the critical byproducts of these peroxisomal oxidases as a result of oxidation of a variety of substrates. Peroxisomal oxidases participate in purine metabolism, fatty acid oxidation, amino acid metabolism, and polyamine metabolism, among others. Absence of urate oxidase enzymatic activity in humans and anthropoid apes and the clear lack of urate oxidase containing crystalloid cores in human liver peroxisomes provided the stimulus for us to clone rat urate oxidase gene. ${ }^{40,41}$ Recombinant urate oxidase expressed in insect cells or in African green monkey kidney (CV-1) cells, using the full-length rat cDNA, exhibited typical crystalloid structure. ${ }^{42,43}$ We and others also cloned human urate oxidase gene and found that it contains multiple mutations, especially two nonsense mutations, one at amino acid position 33 and the other at amino acid position 187.44,45 These mutations are the result of a single nucleotide change from a $\mathrm{C}$ to $\mathrm{T}$ in the second and fifth exons of the gene, converting a CGA arginine codon to TGA stop codon. The stop codon at amino acid position 33 is also found in the three great apes, chimpanzee, gorilla, and orangutan, suggesting that this may be the original mutation responsible for silencing or inactivation of the urate oxidase gene during hominoid evolution. ${ }^{44}$ Of the variety of other oxidases present in peroxisomes, fatty acyl-CoA oxidase and the other enzymes of the fatty acid $\beta$-oxida- 

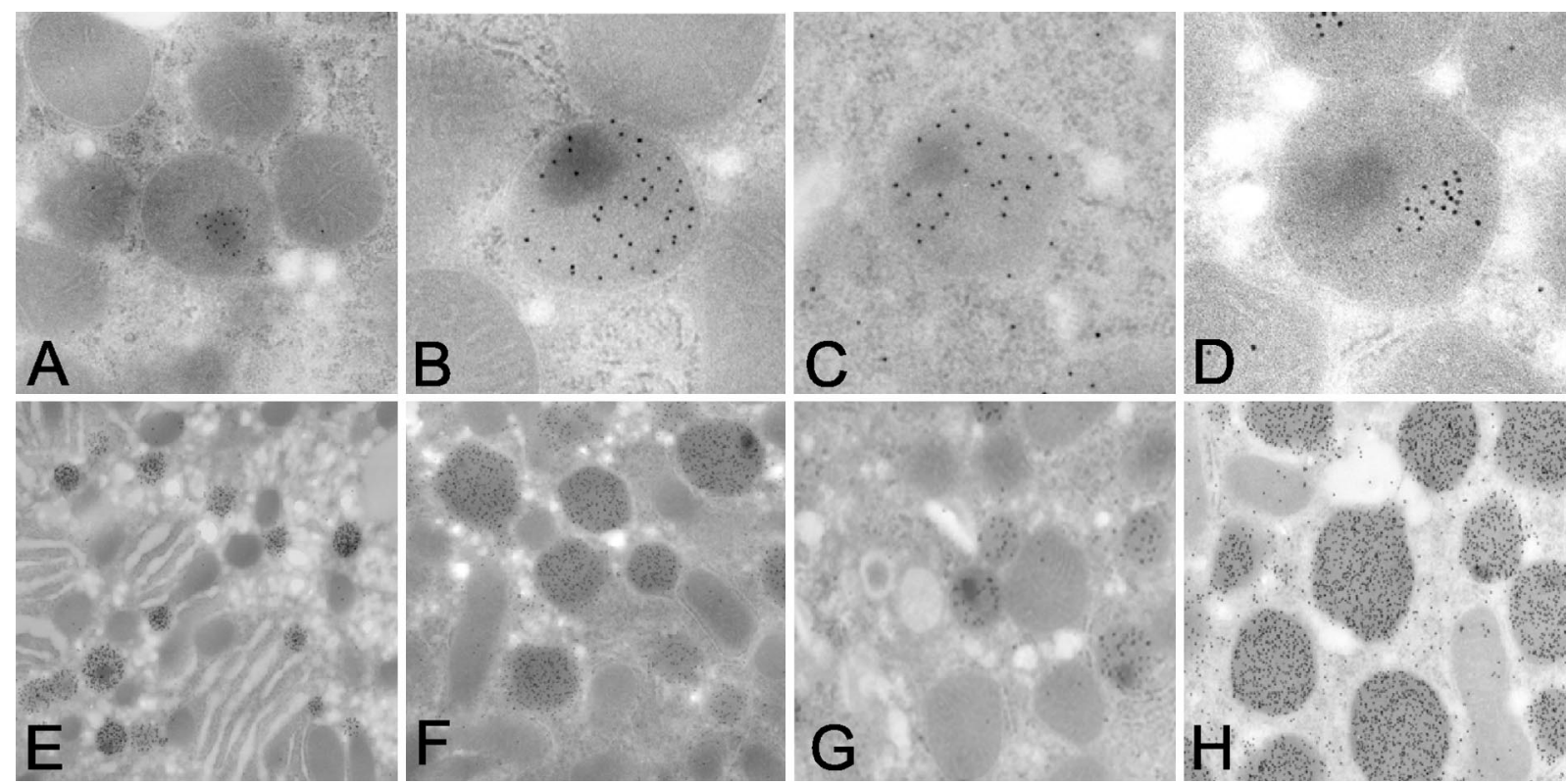

Figure 3. Protein A-gold immunocytochemistry. A, urate oxidase; $\mathbf{B}$, acyl-CoA oxidase; $\mathbf{C}, \alpha$-hydroxyacid oxidase; $\mathbf{D}$, d-amino acid oxidase; $\mathbf{E}$, catalase, normal liver; D, catalase, Wy-14643 treated liver; G, L-PBE, normal liver; H, L-PBE, DEHP-treated liver.

tion system have been well characterized and are of major importance in any consideration of xenobiotic-induced peroxisome proliferation and PPAR $\alpha$ activation. Likewise, the fatty acid oxidation system enzymes appear crucial for energy combustion, necessitating a cross-talk between fatty acid oxidation substrates and PPAR $\alpha .{ }^{46}$

\section{Peroxisome Proliferation and Peroxisome Proliferators}

Peroxisomes are single membrane-limited cytoplasmic organelles which are present in a wide variety of cells in animals and plants. In liver parenchymal cells, peroxisomes measure $\sim 0.2$ to $1 \mu \mathrm{m}$ in diameter and are very few in number, accounting for less than $2 \%$ of cytoplasmic volume under physiological conditions. Peroxisomes in liver parenchymal cells of several species of animals are easily identifiable due to the presence of crystalloid cores or nucleoids containing the enzyme urate oxidase. As mentioned above, in some species, including the human, peroxisomes lack nucleoids, signifying the absence of the enzyme, urate oxidase. ${ }^{38}$ In liver and other tissues that are processed for the localization of catalase, peroxisomes appear as dense brown granules at the light microscopic level (Figure 1), and at the ultrastructural level as dark osmiophilic structures (Figure 2). The catalase cytochemistry provides a dramatic distinction to appreciate the distribution of peroxisomes in normal liver and compare with livers with peroxisome proliferation (Figures 1 and 2). In livers with peroxisome proliferation, these organelles can occupy up to $25 \%$ of hepatocyte cytoplasmic volume. Since the first description of the induction of microbody (peroxisome) proliferation in liver parenchymal cells of rats fed a diet containing clofibrate, a lipid lowering drug in 1965, ${ }^{1}$ we systematically screened several chemicals that induce hepatomegaly and or lower serum lipids for peroxisome proliferative property. ${ }^{6-8,47}$ Structure biological activity studies with clofibrate analogues established a link between hypolpidemic property and peroxisome proliferative effect. ${ }^{47}$ Several of the structural analogues of clofibrate are extremely potent inducers of hepatic peroxisome proliferation in rats and mice. These included methyl clofenapate, and nafenopin, which are several orders of magnitude more potent than the prototype compound, clofibrate, in inducing hepatic peroxisome proliferation. It could not be decided if this indicates a structure-function relationship or coincidentally related properties of structurally closely related clofibrate-like compounds. ${ }^{47}$ We then studied the nature of the hepatomegalic effects of two novel compounds, [4-chloro-6-(2, 3-xylidino)-2-pyrimidinylthio] acetic acid (Wy-14, 643) and 2-chloro-5-(3, 5-dimethylpiperidinosulfonyl) benzoic acid (tibric acid) (Figure 4). Both of these compounds exhibited a potent lipid lowering effect and also caused massive hepatomegaly with profound proliferation of peroxisomes in rat and mouse liver cells (Figures 1 and 2). The stimulation of hepatic peroxisome proliferation by these structurally unrelated hypolipidemic compounds suggested that the peroxisome proliferative property and hypolipidemic responses are interrelated. ${ }^{9}$ Because of the structural diversity of these agents, we decided to call them peroxisome proliferators, to highlight their common biological property. ${ }^{9}$ We subsequently identified that certain phthalate-ester plasticizers, such as di-(2-ethylhexyl)-phthalate (DEHP), and di-(2-ethylhexyl) adipate (DEHA), used in the manufacture of polyvinyl chloride plastics, also induce peroxisome proliferation and exhibit a lipid lowering property. ${ }^{48}$ Several other clofibrate analogues, such as fenofibrate, gemfibrozil, and ciprofibrate were also identified as potent peroxisome proliferators. ${ }^{17,49,50}$ These are currently used as lipid lowering drugs. The frequent association of hepatic 
<smiles>CCOC(=O)C(C)(C)c1ccc(Cl)cc1</smiles>

d<smiles>Cc1ccccc1Nc1cc(Cl)nc(SCC(=O)O)n1</smiles>

b<smiles>CC(C)(O)C(C)(O)Oc1ccc(C2CCCc3ccccc32)cc1</smiles>

e<smiles>CC1CC(C)CN(S(=O)(=O)c2ccc(Cl)c(C(=O)O)c2)C1</smiles>

c<smiles>CC(C)(O)C(C)(O)Oc1ccc(C2CC2Cl)cc1</smiles><smiles>CCC(CC(=O)OCC(=O)c1ccccc1C(=O)OCC(C)C)CC(C)C</smiles>

Figure 4. Structural diversity of peroxisome proliferators. $\mathbf{a}$, clofibrate; $\mathbf{b}$, nafenopin; c, ciprofibrate; d, Wy-14, 643; e, tibric acid; f, di-2(ethylhexy1)phthalate (DEHP).

peroxisome proliferation with drug-induced hypolipidemia suggested that yet unidentified peroxisomal enzymes might be responsible for the hypocholesterolemic and hypotriglyceridemic effects. ${ }^{9}$ These observations served as a solid foundation for the concept that peroxisomes participate in lipid metabolism and for the subsequent discovery of peroxisomal $\beta$-oxidation by Lazarow and De Duve. ${ }^{10}$

\section{Peroxisome Proliferator-Induced Pleiotropic Responses: Immediate and Delayed}

Peroxisome proliferation is a unique phenomenon generated by a wide spectrum of a diverse group of chemicals that include certain hypolipidemic drugs, industrial solvents, phthalate ester plasticizers, herbicides, and others. ${ }^{9,17}$ Despite the structural diversity, peroxisome proliferators, as a group, induce qualitatively predictable pleiotropic responses. These include hepatomegaly, proliferation of peroxisomes in hepatic parenchymal cells, and the induction of several hepatic enzymes, especially those associated with the peroxisome as well as others that participate in lipid metabolism. ${ }^{17-19,50}$ Since all peroxisome proliferators tested thus far in long-term studies have been found to induce liver tumors, the hepatocarcinogenicity of peroxisome proliferators is considered a delayed component of the receptor-mediated pleiotropic responses resulting from prolonged exposure to these agents. ${ }^{15,18,19,50}$ We characterized the peroxisome proliferator-induced hepatic alterations in rats and mice demarcated into two phases, immediate and delayed (or carcinogenic). Short-term treatment results in the immediate or early, adaptive changes, typified by hepatomegaly including liver cell proliferation, hepatic peroxisome proliferation, with attendant increases in selected enzyme activities. ${ }^{9,13,17,51}$ Hepatomegaly is due to massive hypertrophy of hepatocytes in most part resulting from increases in the number of peroxisomes (Figures 1 and 2). We described the initial burst of hepatocellular prolifera-

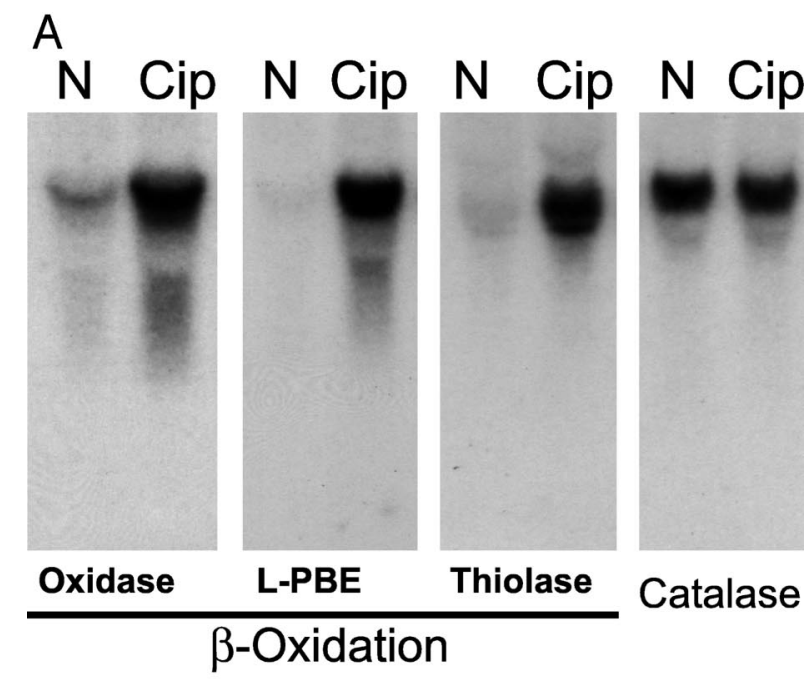

B

\section{L-PBE-induction in Rat Liver}

Peroxisome
Proliferators

Other Proliferators Xenobiotics

L-PBE

L-PBE

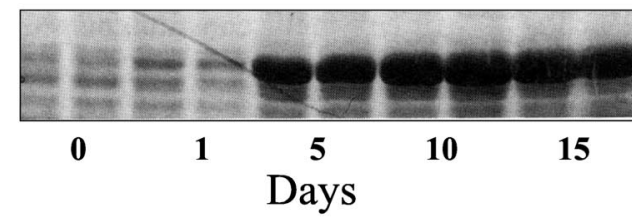

Figure 5. A: Northern blot showing increases in fatty acyl-CoA oxidase, L-PBE, and thiolase mRNA levels in peroxisome proliferator trteated mouse liver as compared to untreated controls. B: SDS-PAGE of liver homogenates reveals increases in 78-kd L-PBE protein in peroxisome proliferator treated livers.

tion induced by peroxisome proliferators as primary mitogenic response, and not a reparative hyperplasia, as these agents are not necrogenic at the doses stimulating peroxisome proliferation. ${ }^{13}$ These early hepatic effects remain invariant as long as the peroxisome proliferators are administered and regress gradually within a few days of withdrawal of treatment. ${ }^{52}$

Early hepatic effects induced by peroxisome proliferators are associated with increased transcription of genes responsible for the peroxisomal $\beta$-oxidation. ${ }^{24}$ Proliferation of peroxisomes in liver is associated with up to $\sim 30$ fold or greater increase in the activities of the enzymes required for peroxisomal $\beta$-oxidation of fatty acids. ${ }^{24}$ We showed that the increased activities of the three enzymes of the peroxisomal $\beta$-oxidation system, fatty acyl-CoA oxidase (AOX), enoyl-CoA hydratase/L-3-hydroxyacylCoA dehydrogenase bifunctional enzyme (L-PBE), and 3-ketoacyl-CoA thiolase (Figure 5A) are due to the rapid and coordinated transcriptional activation of the nuclear genes encoding these enzymes. ${ }^{24}$ Protein profiling studies, using traditional SDS-PAGE analysis or high 


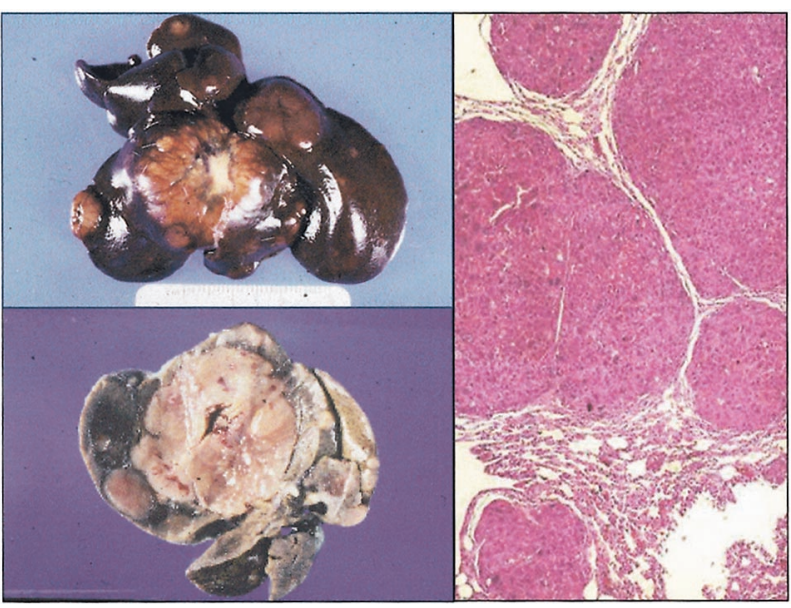

Figure 6. Hepatocellular carcinomas in rat and mouse liver (top left and bottom left) and metastases to lungs (right).

resolu13tion two-dimensional gel electrophoresis, revealed predictable alterations in the amounts of several proteins, including marked induction of peroxisome proliferation-associated protein L-PBE in the livers of rats treated with ciprofibrate, Wy-14, 643, or DEHP (Figure $5 B) .{ }^{53,54}$ It is also of interest that the concentration of catalase mRNA in liver did not change appreciably, suggesting differential regulation of peroxisomal enzymes in livers with peroxisome proliferation. ${ }^{55}$ Catalase activity increases $\sim 2$ - to 3-fold in livers with peroxisome proliferation and recent protein profiling data show up to $\sim 6$-fold increase in the amount of this protein. ${ }^{54}$

\section{Peroxisome Proliferators Form a Novel Class of Chemical Hepatocarcinogens}

Sustained hepatomegaly and increase in hepatic peroxisome proliferation in rats and mice exposed to peroxisome proliferators suggested early on that we undertake detailed studies to ascertain the long-range consequences. We reported the development of hepatocellular carcinomas in mice fed a diet containing nafenopin, a peroxisome proliferator in 1976. ${ }^{11}$ Subsequently, we demonstrated the hepatocarcinogenicity of other, structurally dissimilar, peroxisome proliferators and proposed that these agents constitute a novel class of nongenotoxic carcinogens. ${ }^{12-15}$ These tumors are generally multiple in the liver and show characteristic morphology of hepatocellular carcinomas (Figure 6). Some of these also metastasize to the lungs. Since our initial postulation that peroxisome proliferators are carcinogenic, several other peroxisome proliferators, including hypolipidemic compounds and the plasticizers, DEHP and DEHA, have been shown to induce liver tumors in rats and mice. ${ }^{56,57}$ The latency period and the incidence of tumors correlated well with the effectiveness of the compound to induce hepatomegaly and peroxisome proliferation. ${ }^{56,58}$ Potent peroxisome proliferators, such as Wy-14, 643, ciprofibrate, nafenopin, BR-931, and tibric acid, induced liver tumors in nearly $100 \%$ of rats and or mice within 50 to 60 weeks when administered at dietary concentrations ranging from 0.2 to $0.025 \%(\mathrm{w} / \mathrm{w}) .^{15}$ With less potent peroxisome proliferators (clofibrate and DEHP), liver tumors developed between 70 and 104 weeks at dietary levels ranging from 0.5 to $1.2 \%(\mathrm{w} / \mathrm{w}){ }^{56-58} \mathrm{~A}$ close concordance with the magnitude of hepatic peroxisome proliferation and liver development has been demonstrated and it is now fairly well established that all peroxisome proliferators are potentially carcinogenic. ${ }^{50,56}$

\section{Peroxisome Proliferators are Nonmutagenic Chemical Carcinogens}

Based on the mechanism of action, chemical carcinogens are classified as genotoxic (mutagenic) and nongenotoxic (nonmutagenic) agents. ${ }^{59}$ The genotoxic chemicals covalently react with the DNA and are identifiable using several short-term in vitro and in vivo assays that measure DNA damage, mutagenic effects, and chromosomal aberrations. ${ }^{59}$ We wanted to ascertain whether the structurally diverse peroxisome proliferators induce mutations/DNA damage in short-term mutagenesis and DNA damage-repair assays. ${ }^{16}$ None of these compounds caused detectable mutagenic activity in the Salmonella/microsome assay, or produced DNA damage in the Iymphocyte ${ }^{3} \mathrm{H}$-thymidine incorporation assay. ${ }^{16}$ Since our initial proposal that peroxisome proliferators are nongenotoxic/nonmutagenic agents and do not cause DNA damage, either directly or after metabolic activation, none of the peroxisome proliferators have been shown to exert mutagenicity in any prokaryotic or eukaryotic short-term bioassays. ${ }^{16,60,61}$ We also examined the potential interaction of two structurally diverse peroxisome proliferators on rat liver DNA using the ${ }^{32} \mathrm{P}$ post-labeling assay and found no peroxisome proliferator-DNA adducts. ${ }^{62,63}$ Thus, the dictum that none of the carcinogenic peroxisome proliferators interact with DNA or damage DNA still holds, raising intriguing questions about the mechanisms of their carcinogenic action. The functional class of peroxisome proliferators, which includes structurally diverse chemicals, emerged as the first major prototype of nongenotoxic carcinogens. ${ }^{15,17,60}$

\section{Peroxisome Proliferation as a Biological Marker for Hepatocarcinogenicity}

There are no short-term in vitro screening tests to identify whether a chemical that is not genotoxic may prove to be a nongenotoxic carcinogen in animals after long-term exposure or will prove to be a noncarcinogenic chemical. Since all carcinogenic peroxisome proliferators are nonmutagenic chemicals, we proposed that evaluation for the induction of peroxisome proliferation would serve as a useful and practical short-term in vivo test to screen nongenotoxic chemicals and also to predict their carcinogenic effect. Evidence suggests that when peroxisome volume density reaches or exceeds $20 \%$ of cytoplasmic volume of hepatocytes in rats and mice, by the administered dose of a peroxisome proliferator, the liver tumor incidence can be expected to reach nearly 100\% 
level. ${ }^{15,56}$ The liver tumor incidence will be expected to be proportionately lower if the dose levels are far below the maximum dose for the induction of peroxisome proliferation. Accordingly, to test whether a nongenotoxic chemical is a peroxisome proliferator, it would be important to assay using several dose levels.

\section{Peroxisome Proliferator-Induced Liver Tumors Exhibit Unique Phenotype}

The liver tumors induced by peroxisome proliferators in rats and mice are usually multiple. These tumor-bearing livers are generally enlarged and grayish and nontumorous areas appear as intensely dark-brown. Histologically, these hepatocellular carcinomas are trabecular to poorly differentiated in appearance. Metastases in lungs are encountered in some rats and mice with peroxisome proliferator-induced liver tumors (Figure 6). These tumors are not distinguishable from those induced by genotoxic hepatocarcinogens, but we discovered that the hepatocellular carcinomas induced by peroxisome proliferators in rat liver do not express the classical liver tumor markers $\gamma$-glutamyltranspeptidase and the placental form of glutathione S-transferase (GST- $\pi$ ). ${ }^{64,65}$ Protein profiling studies also confirmed the reduction in GST- $\pi$ content in livers with peroxisome proliferation, suggesting that peroxisome proliferators are negative regulators of GST- $\pi$ expression. ${ }^{54}$ We conclude that the expression of stress proteins, such as $\gamma$-glutamyltranspeptidase and GST- $\pi$ genes, is not a prerequisite for the initiation and progression of hepatocarcinogenesis. ${ }^{65}$ Using cDNA microarrays, we investigated the expression profiles of hepatocellular carcinomas and found distinguishing features between tumors induced by genotoxic and nongenotoxic hepatocarcinogens. ${ }^{66}$ These differences may prove to be molecular fingerprints depicting different carcinogenic mechanism(s).

\section{Peroxisome Proliferator-Induced Carcinogenesis: Oxidative Stress and Oxidative DNA Damage}

The nongenotoxic nature of peroxisome proliferators poses an important challenge to delineate their carcinogenic mechanisms. We proposed that disproportionate increases in $\mathrm{H}_{2} \mathrm{O}_{2}$-generating and -degrading enzymes contribute to sustained intrahepatic oxidative stress resulting in indirect oxidative DNA damage contributing to carcinogenesis. ${ }^{15,17-19,46,67}$ At least three potential sources of reactive oxygen radical production contributing to oxidative overload are possible in livers with peroxisome proliferation. First, the activity of fatty acyl-CoA oxidase, the rate-limiting enzyme of the classical inducible $\beta$-oxidation system, increases significantly. We initially considered this as the major source of $\mathrm{H}_{2} \mathrm{O}_{2}$ in the livers of rats and mice exposed chronically to peroxisome proliferators, but development of liver tumors in mice with disrupted acyl-CoA oxidase gene suggested the exis- tence of other potential contributing sources. Second, and equally important, the CYP4A subfamily of enzymes, which are also markedly upregulated, can also contribute to the superoxide and $\mathrm{H}_{2} \mathrm{O}_{2}$ generation. In general, $P 450$ enzymes catalyze the insertion of oxygen into a wide variety of substrates and generate reactive oxygen species. The magnitude of induction of fatty acid metabolizing CYP4A family of enzymes in livers with peroxisome proliferation, parallels the increases noted for peroxisomal fatty acid oxidation enzymes. ${ }^{67}$ The third source of reactive oxygen species production is the overall increases, albeit subtle, of other peroxisomal oxidases, such as urate oxidase in livers with peroxisome proliferation. As pointed out above, in these livers with higher levels of oxidants, increases in catalase activity appear modest, leading to the suggestion of disproportionate increases in enzymes capable of producing and degrading $\mathrm{H}_{2} \mathrm{O}_{2} \cdot{ }^{24,55}$ Equally important is that protein profiling data points to marked down-regulation of several proteins critical for countering the deleterious effects of reactive species, such as selenium binding protein 2 (SBP2) ${ }^{54,68}$ Nearly 18 -fold decrease in SBP2 content has been found in livers. SBPs are believed to play a crucial role in the growth inhibitory and anticarcinogenic effects of selenite by acting as growth regulatory proteins. ${ }^{54}$ In normal liver, peroxisomes appear to account for $20 \%$ of oxygen consumption and this level of oxygen utilization is expected to be higher in livers with increased levels of peroxisomal and microsomal fatty acid oxidation. ${ }^{20,32}$ Both short- and long-term treatment with various peroxisome proliferators resulted in increased levels of 8-hydroxydeoxyguanosine in livers. ${ }^{69}$ Furthermore, ${ }^{32} \mathrm{P}$-postlabeling studies have confirmed the presence of unidentified DNA adducts in the livers of rats treated with a potent peroxisome proliferator, ciprofibrate, but the DNA adducts were not due to chemical-DNA adduction. ${ }^{62,63}$ Consistent with this oxidative DNA damage mechanism is that livers with chronic peroxisome proliferation manifest high levels of lipid peroxidation and lipofuscin pigment, a hallmark of chronic oxidative damage to macromolecules. ${ }^{20,22,23}$ Our work also established significant inhibition of peroxisome proliferator-induced liver carcinogenesis with simultaneous administration of ethoxyquin, a potent antioxidant. ${ }^{21}$ Recent work demonstrates marked induction of genes specific for the long-patch base excision DNA repair, a predominant pathway that removes oxidized DNA lesions, in livers with peroxisome proliferation. ${ }^{70}$ These observations clearly establish that DNA-damaging oxidants are generated by enzymes induced in association with peroxisome proliferation in liver and provide further support for our oxidative stress hypothesis. Oxidative DNA damage most likely contributes to genetic alterations and the smoldering low level cell proliferation that generally occurs in livers with peroxisome proliferation may serve as a contributory and synergistic factor but is unlikely to be the primary cause of cancer. ${ }^{25,50,71}$ Peroxisome proliferators induce liver cell proliferation mostly during the first week or so, ${ }^{13}$ and chronic treatment does not lead to this level of sustained mitogenic action. ${ }^{71}$ Overall, liver cell proliferation per se is unlikely to be a key ingredient in the 
causation of hepatocarcinogenesis, but it might certainly fix a mutation induced by reactive oxygen species. ${ }^{18,19}$ It should be noted that neoplastic transformation of hepatocytes does not occur despite the near unlimited potential of hepatocytes to divide and yet not become neoplastic. ${ }^{72}$ Thus, in liver one can certainly question the proposition that mitogenesis per se is mutagenesis.

\section{Overexpression of Peroxisomal Oxidases and Neoplastic Transformation}

We examined the role of overexpression of peroxisomal fatty acyl-CoA oxidase and urate oxidase in carcinogenesis by generating cell lines stably overexpressing these enzymes. Rat peroxisomal acyl-CoA oxidase, under the transcriptional control of the cytomegalovirus promoter, was transfected into African green monkey kidney (CV-1) cells and a cell line stably overexpressing the enzyme was derived. ${ }^{73}$ When exposed to a fatty acid substrate, this cell line formed transformed foci, grew efficiently in soft agar, and developed into adenocarcinomas when transplanted into athymic nude mice. ${ }^{73}$ Similar results were obtained when this enzyme was overexpressed in a nontumorigenic rat urothelial cell line, MYP-3. ${ }^{74}$ These fatty acyl-CoA overexpressing urothelial cells, when exposed to fatty acid substrate, demonstrated strikingly higher $\mathrm{H}_{2} \mathrm{O}_{2}$ levels and formed colonies in soft agar in proportion to the duration of exposure to linoleic acid. ${ }^{74}$ In another study, we stably overexpressed fatty acyl-CoA in a nontumorigenic mouse fibroblast cell line (LM-tk-) under the control of mouse urinary protein promoter. ${ }^{75}$ These cells, when treated with a fatty acid for 6 to 96 hours, exhibited $\sim 10$-fold increase in intracellular $\mathrm{H}_{2} \mathrm{O}_{2}$ and apoptosis. ${ }^{75}$ Prolonged exposure to a fatty acid resulted in the transformation of these cells, including tumor formation, when introduced into nude mice. ${ }^{75}$ Overall, these studies clearly establish that prolonged overexpression of $\mathrm{H}_{2} \mathrm{O}_{2}$-generating fatty acyl-CoA oxidase is oncogenic. ${ }^{75}$ Finally, we examined the role of stable overexpression of urate oxidase, another peroxisomal enzyme, in the transformation of CV-1 cells. Urate oxidase converts uric acid to allantoin and, in the process, generates $\mathrm{H}_{2} \mathrm{O}_{2}{ }^{43,76}$ We expressed urate oxidase under the control of constitutively active human peroxisomal fatty acyl-CoA oxidase gene promoter we cloned ${ }^{77}$ and found this promoter functionally intact, unlike claims to the contrary. ${ }^{78,79} \mathrm{CV}-1$ cells stably expressing urate oxidase were exposed to the substrate uric acid and continued exposure to this substrate resulted in transformation and tumorigenicity. ${ }^{76}$ These studies clearly establish the carcinogenic potential of overproduction of $\mathrm{H}_{2} \mathrm{O}_{2}$ by peroxisomal oxidases. Others also obtained similar results by overexpressing superoxidegenerating oxidase Mox1 in NIH3T3 cells. ${ }^{80}$

\section{Evolution of the Peroxisome Proliferator Receptor Concept}

In 1983, we proposed that peroxisome proliferators induce the predominantly liver-specific effects by two pos-

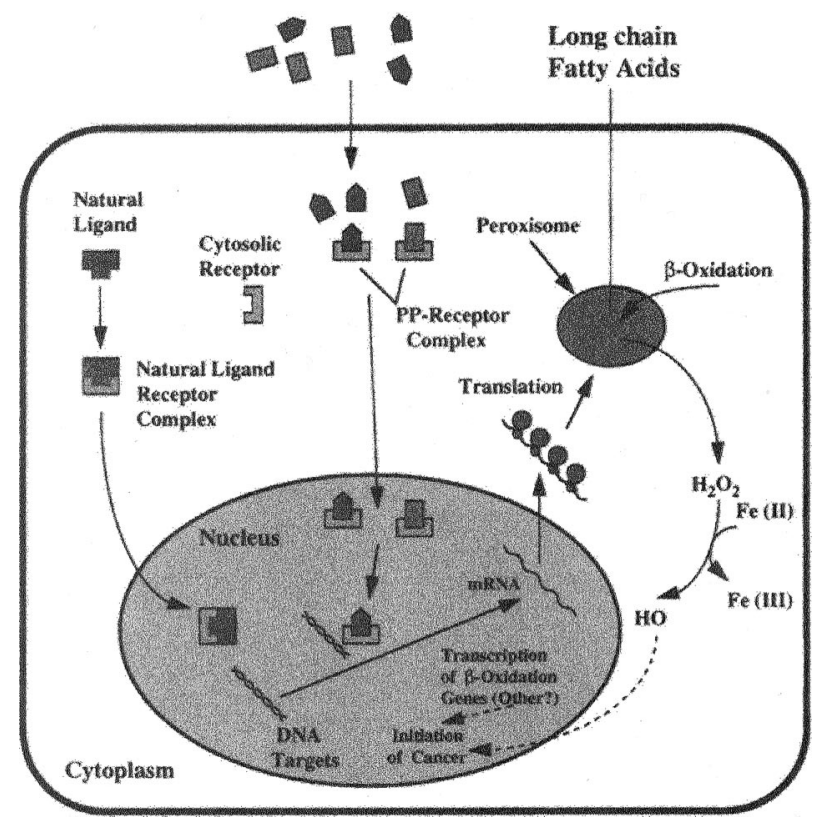

Figure 7. Receptor model for peroxisome proliferator induced pleiotropic responses (adapted from reference 86).

sible mechanisms. These include exerting their effects through a ligand receptor-mediated mechanism and by increasing the influx of lipids into the liver. ${ }^{17}$ We subsequently accumulated convincing evidence, in favor of the receptor-mediated signal transduction hypothesis. ${ }^{17-19}$ From a historical perspective, it would be appropriate to recapitulate the following: the similarity of biological/ pleiotropic responses induced by dissimilar peroxisome proliferators; ${ }^{9}$ hepatocyte-specific induction of these pleiotropic effects and the fact that similar magnitude of peroxisome proliferation in other cell types does not occur; ${ }^{55}$ fidelity of the response of extrahepatic hepatocytes (transplanted either subcutaneously ${ }^{81}$ or in the anterior chamber of eye, ${ }^{82}$ ) and hepatocytes developing in pancreas in rats with copper deficiency induced acinar cell depletion ${ }^{83}$ to the inductive effects of peroxisome proliferators implying that hepatocytes irrespective of their location can recognize and respond to peroxisome proliferators; induction of specific changes in protein composition in the livers of rats/mice treated with structurally different peroxisome proliferators; ${ }^{53}$ rapid and coordinated transcriptional activation of the peroxisomal $\beta$-oxidation system genes by different peroxisome proliferators, ${ }^{24}$ and the detection of a specific peroxisome proliferator binding moiety in liver cytosol. ${ }^{84-86}$ Based on this information, we proposed a model that peroxisome proliferators act by receptor-mediated mechanism and that synthetic (chemical peroxisome proliferators) and natural (fatty acids) ligands act by this mechanism to induce specific genes and that cancer is due to oxidative stress caused by the induction of enzyme systems (Figure 7). Since peroxisome proliferation occurs in extrahepatic locations but not in the adjacent nonhepatic cells in these locations it became clear that liver cells possess a mechanism to recognize these xenobiotics. Thus, the hepatocytes show a biological response to peroxisome 
proliferators irrespective of their location in the body. This glaring biological fact, together with rapid coordinated transcriptional activation of lipid metabolizing genes and the specific, albeit weak, binding moiety in liver cytosol laid a solid foundation for the peroxisome proliferator receptor mechanism. ${ }^{24,81-86}$ Our biochemical purification approaches yielded several peroxisome proliferator binding proteins, including a 55-kd protein, heat-shock 70 protein, and a few others but the nature of receptor was far from clear. ${ }^{85,86}$ Nonetheless, these observations and the concept formed the impetus for molecular cloning of the receptor. A mouse peroxisome proliferatoractivated receptor (PPAR) was cloned from the liver, in 1990, by Issemann and Green ${ }^{26}$ using transactivation assays. A high-level expression of PPAR mRNA was noted in liver and kidney, and its expression in other tissues was less pronounced, confirming the documented pattern of tissue-specific effects of peroxisome proliferators. $^{26,55}$ In essence, the molecular cloning of this nuclear receptor for peroxisome proliferators confirmed our hypothesis and a series of other concepts generated earlier. In retrospect, multiple peroxisome proliferator binding proteins identified by us initially by affinity purification approach, ${ }^{85}$ in some part, represented a complex which we recently identified as peroxisome proliferator interacting protein complex. ${ }^{87}$

\section{PPAR Family of Nuclear Receptors and PPAR $\alpha$ as a Sensor for Xenobiotic Peroxisome Proliferators}

The cloning of the mouse PPAR in 1990 heralded a new era of biotic and xenobiotic sensing by liver. ${ }^{26}$ This also paved the way for finding ligands for other orphan nuclear receptors in rapid succession during the past decade. ${ }^{88}$ Soon after the cloning of the mouse PPAR (now $\operatorname{PPAR} \alpha$ ), three isoforms of PPAR, designated $\alpha^{-}, \gamma^{-}, \beta$ (also called $\delta$ ), have been cloned from Xenopus. ${ }^{27} \mathrm{We}$ then reported the cloning of mouse PPAR $\gamma$ from the liver in 1993. ${ }^{89}$ This was followed by cloning of PPAR $\gamma 2$ from adipocytes $^{90}$ and other PPAR isoforms from other mammalian sources, including human. ${ }^{91,92}$ The PPAR isotypes are encoded by separate genes, with PPAR $\gamma$ gene yielding two major transcripts, PPAR $\gamma 1$ and PPAR $\gamma 2$, resulting from differential mRNA splicing and alternate promoter usage (Figure 8). ${ }^{93}$ Like other nuclear receptors, PPARs possess a highly conserved DNA binding domain, with two zinc fingers, that recognizes peroxisome proliferator response elements (PPREs) in the promoter regions of target genes. ${ }^{50,92}$ PPARs also contain two transcriptional activation function (AF) domains, termed $\mathrm{AF}-1$ in the N-terminal domain and AF-2 in the ligand binding domain. ${ }^{92}$ After ligand binding, PPARs heterodimerize with another nuclear receptor, the retinoid- $X$ receptor (RXR), and the PPAR/RXR heterodimers bind to DNA sequences containing direct repeats of the hexanucleotide sequence AGGTCA separated by one nucleotide, known as direct repeat 1 (DR-1) response element. ${ }^{94}$ The promoter regions of PPAR target genes

\section{Peroxisome Proliferator-Activated Receptor (PPAR) family}

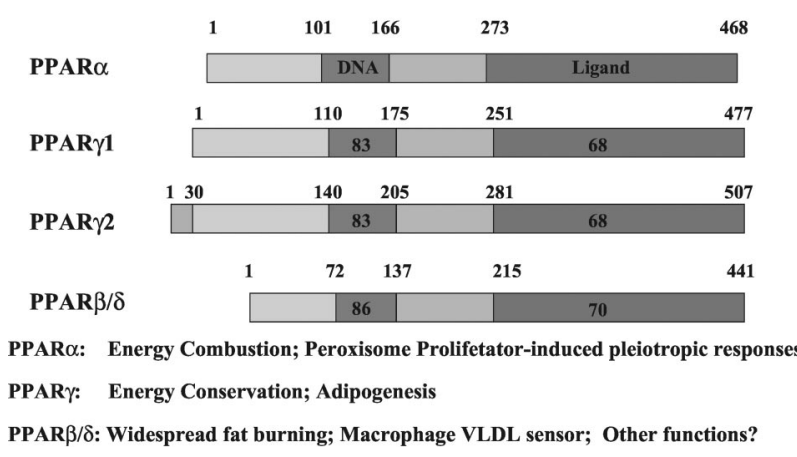

Figure 8. Peroxisome proliferator-activated receptor family consists of three members: PPAR $\alpha, \operatorname{PPAR} \gamma$, and $\operatorname{PPAR} \beta / \delta$ (adapted from reference 104).

contain this PPRE sequence or minor variants of the consensus sequence: 5'-AGGNCA A AGGTCA-3'.92

PPARs are expressed in all tissues, and are activated by a variety of synthetic ligands, such as peroxisome proliferators, and biological molecules, such as polyunsaturated fatty acids and eicosanoids. ${ }^{50,92,95}$ Differing levels of expression of these molecules, raises the question as to which factors determine the cellular- and genespecific responses to a wide variety of PPAR ligands and how PPREs of a given target gene recognize a particular PPAR isotype. Differences in the tissue distribution and in the ligand binding domain attest to the fact that they perform different functions. ${ }^{92}$ PPAR $\alpha$ is expressed in the liver, kidney, intestine, and heart and the gene-knockout mouse model (PPAR $\alpha^{-1-}$ ) unequivocally establishes that it is the critical player in peroxisome proliferator-induced pleiotropic responses and in the hepatic combustion of energy, mainly fatty acids. ${ }^{96}$ Absence of PPAR $\alpha$ abrogates the pleiotropic responses in liver induced by peroxisome proliferators, including the development of liver cancer. ${ }^{96,97}$ The cloning of PPAR $\alpha$ and the generation of PPAR $\alpha^{-1-}$ mouse, which establishes the role of this receptor in peroxisome proliferator-induced pleiotropic responses, clearly validates the receptor concept we proposed in 1983. ${ }^{17}$ All synthetic peroxisome proliferators, including clofibrate family of fibrates, Wy-14, 643, phthalate ester plasticizers, and herbicides, function as PPAR $\alpha$ ligands. Thus, PPAR $\alpha$ functions as the hepatic sensing mechanism to recognize xenobiotic peroxisome proliferators and endogenous ligands, in particular fatty acid intermediates generated during fatty acid oxidation among others.

Of the other two members of PPAR family, PPAR $\beta / \delta$ is expressed broadly in many tissues and appears to participate in growth, development, and in up-regulating energy combustion, in particular, in extrahepatic tissues similar to that of PPAR $\alpha .{ }^{98,99}$ However, PPAR $\beta / \delta$ does not function as a receptor for peroxisome proliferator-mediated induction of pleiotropic responses in liver in the absence of PPAR $\alpha .{ }^{96,100} \operatorname{PPAR} \gamma$, unlike PPAR $\alpha$ and $\operatorname{PPAR} \beta / \delta$, plays a major role in adipogenesis and energy storage, with PPAR $\gamma 2$ expressed predominantly in adipose tissue and PPAR $\gamma 1$ in many tissues at relatively low 
levels. ${ }^{90}$ The synthetic chemicals that function as PPAR ligands include the thiazolidinedione class of drugs such as troglitazone, rosiglitazone, and pioglitazone..$^{91,92}$ PPAR $y$ increases adipocyte conversion to accommodate the storage of excess energy in the body as triacylglycerols by increasing adipocyte-specific gene expression and differentiation. ${ }^{91,92}$ In this context, overexpression of either PPAR 1 or PPAR 2 leads to adipogenic conversion of fibroblasts and overexpression of PPAR $\gamma 1$ in liver has resulted in adipogenic hepatic steatosis. ${ }^{101,102}$ Gene expression profiling of livers overexpressing PPAR $y$ revealed induction of adipocyte-specific and lipogenesisrelated genes in association with the onset of adipogenic hepatic steatosis. ${ }^{102}$ Induction of adipsin, adiponectin, aP2, caveolin-1, fasting-induced adipose factor (angiopoeitin-like 4), and others in liver point to adipogenic transformation of liver cells. ${ }^{102}$ These observations are of potential significance in that PPAR $\gamma$ ligands may induce adipocyte-specific differentiation in certain neoplastic and nonneoplastic epithelial tissues, including liver.

\section{PPAR $\alpha$ Target Genes}

Peroxisome proliferators induce immediate (short-term) and delayed (chronic) pleiotropic responses, which were attributed to be mediated by a postulated receptor before the cloning of PPAR $\alpha .{ }^{17}$ As a result, all peroxisome proliferators essentially function as PPAR $\alpha$ ligands. Genes that were transcriptionally activated by peroxisome proliferators are now identified as PPAR $\alpha$ target genes and, in most of these, functional PPREs have been found in their promoter regions. ${ }^{50,92}$ Peroxisomal $\beta$-oxidation genes were first identified as PPAR $\alpha$ target genes because of their rapid and coordinated transcriptional induction in liver. ${ }^{24,50}$ Peroxisomal $\beta$-oxidation consists of four steps. ${ }^{46}$ Each metabolic conversion can be performed by at least two distinct enzymes. The classical peroxisome proliferator-inducible pathway (Figure 9) utilizes straight-chain acyl-CoAs as substrates, whereas the second, mostly noninducible, pathway catalyzes the oxidation of 2-methylbranched fatty acyl-CoAs. In the classical inducible $\beta$-oxidation pathway, dehydrogenation of acyl-CoA esters to their corresponding trans-2-enoylCoAs is catalyzed by fatty acyl-CoA oxidase (AOX) and the second and third reactions, hydration and dehydrogenation of enoyl-CoA esters to 3-ketoacyl-CoA, are catalyzed by a single enzyme, enoyl-CoA hydratase/L-3hydroxyacyl-CoA dehydrogenase (L-bi-/multifunctional enzyme (L-PBE/MFP1)) ${ }^{46}$ The third enzyme of this inducible system, 3-ketoacyl-CoA thiolase, converts 3-ketoacyl-CoA to acetyl-CoA and an acyl-CoA that is two carbon atoms shorter than the original molecule and the two carbon-shortened acyl-CoA then re-enters the $\beta$-oxidation cycle. ${ }^{46}$ The three genes encoding for these three proteins of the inducible $\beta$-oxidation system are regulatable by PPAR $\alpha .{ }^{24,96}$ We reported the cloning of human AOX gene using the P1 clone no. 177 that we obtained from the human foreskin fibroblast P1 bacteriophage library (Genome Systems, St. Louis, MO). ${ }^{77,103}$ The original PPRE published from this human P1 bacteriophage

\section{Peroxisomal Fatty Acid $\beta$-oxidation}

Fatty acid + CoA

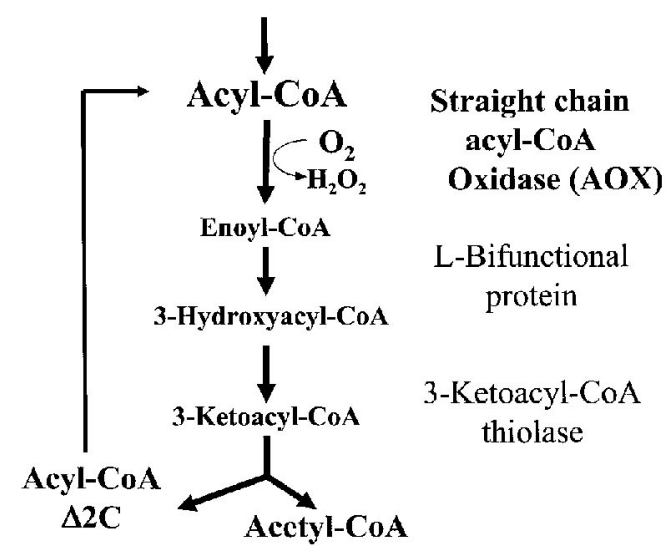

Figure 9. Inducible classical peroxisomal $\beta$-oxidation system. Staright chain acyl-CoA oxidase uses oxygen to generate hydrogen peroxide. Disruption of this gene results in massive spontaneous peroxisome proliferation in liver cells.

clone no. 177 had a typographical error, CTG instead of GCT, in the reported sequence AGGTCA C TGGTCA. The corrected sequence published after resequencing of the original P1, one freshly obtained from Genome Systems and of the pHACOXUOX, ${ }^{77}$ and DNA obtained from three human genomic DNA samples showed identical PPRE consisting of 5'-AGGTCA G CTGTCA-3'. ${ }^{77}$ Unfortunately, this corrected evidence was ignored by Roberts and her co-workers ${ }^{78,79}$ and a mistaken notion that human AOX promoter was nonfunctional has been promulgated, in part, to assert that a noninducible human AOX will possibly reduce the potential risk to humans of chronic exposure to PPAR $\alpha$ ligands. If human AOX gene is uninducible, as claimed by Roberts and her colleagues, ${ }^{78,79}$ one would expect severe metabolic syndromes and hepatic dysfunction in humans, since they would not be able to sense the influx of fatty acids into the liver and respond accordingly. ${ }^{46,104}$

As pointed out above, L-PBE, the second enzyme of the peroxisomal $\beta$-oxidation system, becomes most inducible in the liver of rats and mice in response to PPAR $\alpha$ ligands. ${ }^{54}$ The genetic basis of this hyperinduction may be due to four imperfect TGACCT half-sites in its promoter that constitute an unique binding with two DR1 elements overlapping a DR2 element. ${ }^{105}$ The PPREs of L-PBE gene appear to bind with one or two PPAR/RXR heterodimers providing the peroxisome proliferator-signaling pathway with two levels of response. The peroxisomes also possess a second, generally noninducible, $\beta$-oxidation system, which acts on branched fatty acylCoA esters. ${ }^{46}$ Although the oxidases and D-PBE of this system are not inducible by PPAR $\alpha$ ligands, the gene encoding for the third enzyme, sterol carrier protein $x$ (SCPx), which possesses thiolase activity, is inducible. ${ }^{66}$ The gene encoding for SCPx (58-kd protein) also codes for a smaller 5.3-kd protein (SCP2 or nonspecific lipid transfer protein). ${ }^{66,106}$ 
Genes encoding for microsomal CYP4A family (CYP4A1 and CYP4A3) $\omega$-oxidation enzymes, mitochondrial $\beta$-oxidation enzymes (especially medium chain acylCoA dehydrogenase), liver fatty acid binding protein, lipoprotein lipase, apolipoprotein A-I, A-II, and C-III, and some other cytosolic proteins were subsequently identified as PPAR $\alpha$ target genes. ${ }^{50,92}$ The livers with peroxisome proliferation and PPAR $\alpha$ activation are transcriptionally geared toward fatty acid combustion. Recent work, using cDNA microarray and protein profiling approaches, has identified several novel PPAR $\alpha$ target genes in liver. ${ }^{107}$ These include pyruvate dehydrogenase kinase-4 (PDK4), peroxisomal biogenesis factor $11 \beta$, as well as several cell recognition surface proteins including annexin A2, CD24, CD39, CD36, lymphocyte antigen 6D, and many others. Enhanced expression of several of these genes identified in microarray screening was confirmed in Wy-14, 643-treated mouse livers by Northern analysis and an obligatory role for PPAR $\alpha$ in the induction of these genes has been demonstrated. ${ }^{107}$ Additional studies are necessary to ascertain the presence of PPRE in the promoter regions of these newly regulated genes in livers with peroxisome proliferation.

\section{Peroxisomal Fatty Acid Oxidation: Gene Knockout Mouse Models}

Of the three PPAR isotypes, PPAR $\alpha$ plays prominent role in the hepatic catabolism (combustion) of energy. PPAR $\alpha$ tightly regulates constitutive and peroxisome proliferatorinducible levels of expression of genes involved in peroxisomal, mitochondrial, and microsomal fatty acid oxidation. ${ }^{24,96,108}$ Mice deficient in PPAR $\alpha$ exhibited reduced levels of mitochondrial $\beta$-oxidation in liver as compared with wild-type mice. ${ }^{108}$ On the other hand, the constitutive expression of enzymes involved in peroxisomal $\beta$-oxidation of very long-chain fatty acids was unaffected in PPAR $\alpha^{-1-}$ mouse livers. These observations clearly point to the criticality of maintaining basal unaltered expression of peroxi-

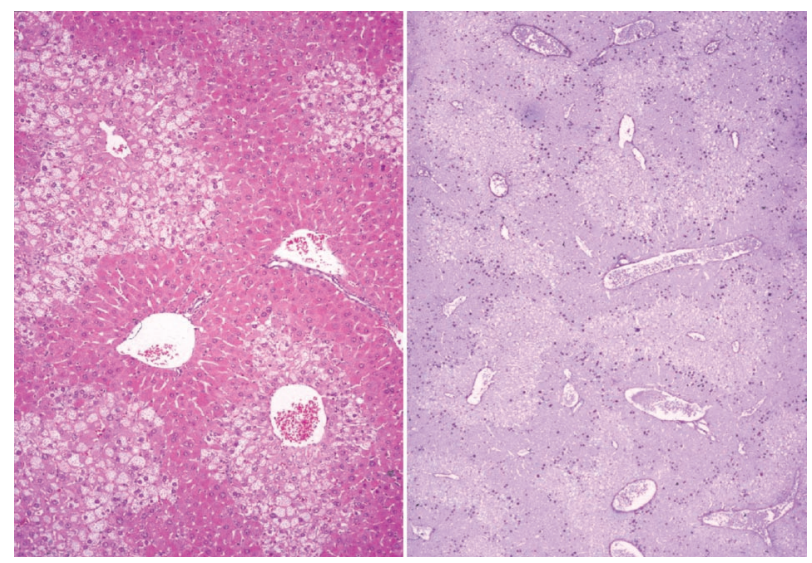

Figure 10. Fatty acyl-CoA oxidase null mouse liver. Note the progressive replacement of steatotic hepatocytes with regenerating heaptocytes that extend toward the centrizonal region (left) and nuclear labeling of bromodeoxyuridine incorporation to show cell proliferation (left) resulting in the emergence of hepatocytes that are devoid of fat but rich in peroxisomes (see Figure 11, right).

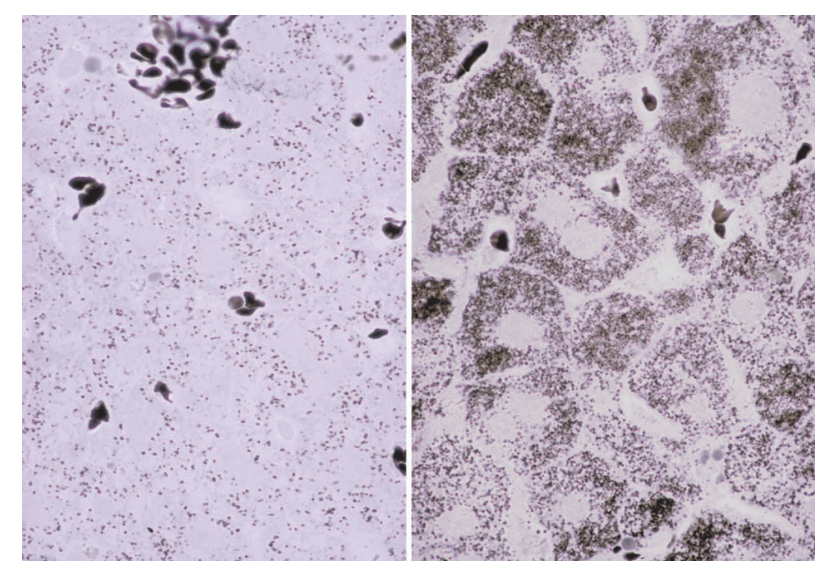

Figure 11. Spontaneous peroxisome proliferation in fatty acyl-CoA oxidase null mouse (right) as compared with normal mouse liver (left). Sections processed for catalase localization.

somal enzymes in that any drastic reductions in peroxisomal fatty acid $\beta$-oxidation may lead to adverse effects. In fact, disturbances in peroxisomal fatty acid oxidation are known to lead to serious abnormalities including death in children. ${ }^{109}$ To investigate the impact of disturbances in peroxisomal fatty acid oxidation we generated mice lacking: $\mathrm{AOX}\left(\mathrm{AOX}^{-1-}\right) ; 1^{110}$ both $\mathrm{AOX}$ and PPAR $\alpha\left(\mathrm{AOX}^{-1-} / \mathrm{PPAR}^{-1-}\right){ }^{100}$ L-PBE, ${ }^{111}$ and L-PBE and D-PBE (L-PBE $\left.{ }^{-1-} / \mathrm{D}_{-} \mathrm{PBE}^{-/-}\right){ }^{106}$ The genetically altered mouse models we generated underscore the importance of PPAR $\alpha$ and of the criticality of peroxisomal AOX and other enzymes of the enzyme $\beta$-oxidation system. ${ }^{104}$ The following represents a brief summary of some important observations.

\section{FASTING $\longrightarrow$ ADIPOSE TISSUE / LIPOLYSIS \\ FATTY ACID INFLUX NG / OXIDATION}

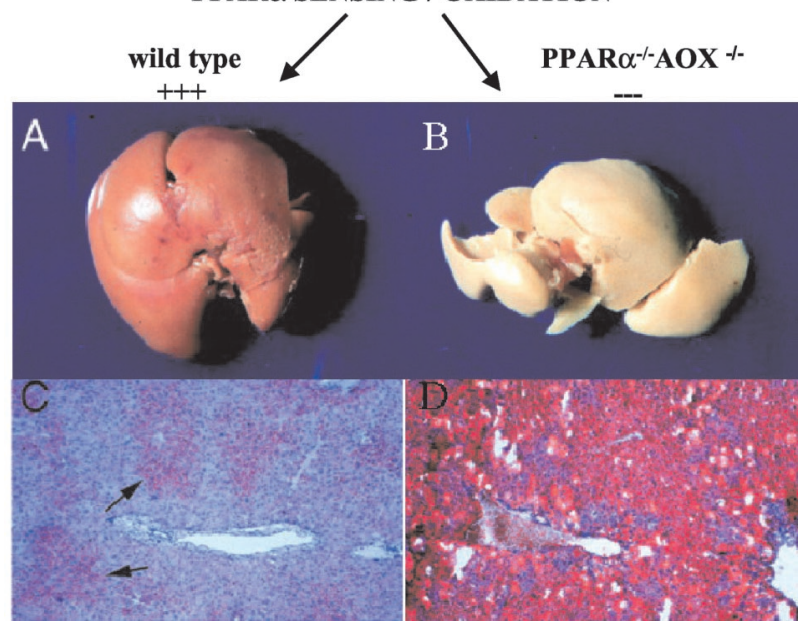

Figure 12. Mice deficient in both PPAR $\alpha$ and fatty acyl-CoA oxidase $\left(\mathrm{PPAR}^{-/-} \mathrm{AOX}^{-/-}\right)$develop severe steatosis when subjected to fasting, as they cannot upregulate PPAR $\alpha$-dependent fatty acid oxidation systems. A and $\mathbf{C}$, wild-type fasted; $\mathbf{B}$ and $\mathbf{D}$, double null mouse liver fasted (adapted from reference 113). 


\section{AOX Is Required for the Metabolic Degradation of PPAR $\alpha$ Ligands}

We generated mice lacking AOX, the first enzyme of the inducible straight-chain fatty acid oxidation system by homologous recombination. ${ }^{110}$ These mice serve as valuable tools to investigate the functional implications of disrupting the PPAR $\alpha$-independent basal peroxisomal metabolism of very long-chain fatty acids. ${ }^{110}$ We noted that $\mathrm{AOX}^{-1-}$ mice developed severe microvesicular steatohepatitis, increased intrahepatic $\mathrm{H}_{2} \mathrm{O}_{2}$ levels, and hepatocellular regeneration that eventually leads to complete replacement of steatotic hepatocytes with regenerated hepatocytes that exhibit massive spontaneous peroxisome proliferation (Figures 10 and 11). The $\mathrm{AOX}^{-1-}$ mouse livers also reveal marked increases in the expression of PPAR $\alpha$ target genes. ${ }^{110,112}$ Older $\mathrm{AOX}^{-1-}$ mice also develop spontaneous hepatocellular carcinomas due to sustained activation of PPAR $\alpha$ and induction of spontaneous peroxisome proliferation. ${ }^{112}$ These observations clearly point to natural ligands of PPAR $\alpha$ that are effectively metabolized by peroxisomal AOX. The presence of this enzyme is crucial for keeping PPAR $\alpha$ in check; in essence, the substrates of AOX act as ligands for PPAR $\alpha$, the transcription factor that regulates the inducible levels of this enzyme. ${ }^{67,112}$ The results obtained from AOX null mouse model also indicate that oxidases of non-inducible branched chain peroxisomal $\beta$-oxidation system are incapable of metabolizing some or all of the unmetabolized AOX substrates by crossover function. ${ }^{112}$ These studies also point to the importance of the maintenance of PPAR $\alpha$-independent basal peroxisomal $\beta$-oxidation activity to metabolize very long-chain fatty acids and other substrates to prevent hepatotoxicity and steatohepatitis. The AOX null mouse model clearly establishes that lack of this enzyme leads to profound changes in liver, including steatohepatitis and transcriptional activation of PPAR $\alpha$ target genes. ${ }^{112}$

\section{Mice Nullizygous for Both PPAR $\alpha$ and AOX}

We generated mice nullizygous for both PPAR $\alpha$ and AOX $\left(\mathrm{AOX}^{-1-} / \mathrm{PPAR} \alpha^{-1-}\right)$ to establish that neither PPAR $\beta / \delta$ nor PPAR $\gamma$ in liver contribute to the phenotype of steatohepatitis, and spontaneous peroxisome proliferation. ${ }^{100,112}$ $\mathrm{AOX}^{-1-} / \mathrm{PPAR}^{-1-}$ mice fail to exhibit microvesicular steatohepatitis, spontaneous peroxisome proliferation, and induction of PPAR $\alpha$-regulated genes by biological ligands that remain unmetabolized in the absence of $\mathrm{AOX} .^{100}$ In $\mathrm{AOX}^{-1-}$ mice, sustained activation of PPAR $\alpha$ enhances the severity of hepatic steatosis by inducing CYP4A family of genes that generate dicarboxylic fatty acids that cannot be metabolized in the absence of AOX. CYP4A enzymes also generate $\mathrm{H}_{2} \mathrm{O}_{2}$, which further contribute to steatohepatitis. ${ }^{67}$ In double null mice, the absence of PPAR $\alpha$ abrogates the generation of dicarboxylic acids, thus pointing to the importance of the induction of CYP4A enzymes in the pathogenesis of steatohepatitis in $\mathrm{AOX}^{-1-}$ mice. $^{100}$
The availability of PPAR $\alpha^{-1-96} \mathrm{AOX}^{-1-110,112}$ and $\mathrm{AOX}^{-1-} / \mathrm{PPAR} \alpha^{-1-100}$ mice enabled us to compare their responses to fasting. ${ }^{113}$ In wild-type mice, fasting for 24 to 72 hours resulted in a modest induction of hepatic expression of PPAR $\alpha$ target genes encoding for fatty acid oxidation enzymes to efficiently metabolize fatty acids influxed into the liver during starvation. In PPAR $\alpha^{-1-}$ livers and in $\mathrm{AOX}^{-1-} / \mathrm{PPAR}^{-1-}$ double nulls, the absence of PPAR $\alpha$ abrogated the induction of these acute stress responses and resulted in severe hepatic steatosis (Figure 12). AOX ${ }^{-1-}$ mice, on the other hand, showed no increase in hepatic steatosis in response to fasting because these animals already exhibit $\operatorname{PPAR} \alpha$ hyperactivity. ${ }^{113}$ These observations establish the critical importance of PPAR $\alpha$ and AOX in energy combustion.

\section{Mice Deficient in Both L-PBE and D-PBE Overexpress PPAR $\alpha$-Regulated Genes in Liver in the Absence of Peroxisome Proliferation}

The AOX null mouse clearly highlighted the genetic importance of this gene in the metabolic degradation of PPAR $\alpha$ ligands. ${ }^{112}$ To further extend the role of peroxisomal $\beta$-oxidation and intermediates generated during fatty acid oxidation, we generated mice lacking L-PBE, the second enzyme of the inducible peroxisomal $\beta$-oxidation system. ${ }^{111} \mathrm{~L}-\mathrm{PBE}^{-1-}$ mice were viable and fertile, and exhibited no detectable gross phenotypic defects. Hepatic steatosis, hepatic peroxisome proliferation, and induction of PPAR $\alpha$ target genes in liver were not noted in $\mathrm{L}-\mathrm{PBE}$, suggesting that disruption of peroxisomal $\beta$-oxidation pathway distal to AOX does not interfere with the inactivation of endogenous ligands. To eliminate the possibility that the substrates of L-PBE can be metabolized by the D-PBE of the branched chain system, we generated mice lacking L-PBE and D-PBE (L-PBE ${ }^{-1-}$ ) $\left.\mathrm{D}-\mathrm{PBE}^{-1-}\right)$, ie, total inactivation of peroxisomal $\beta$-oxidation at the level of second enzyme. ${ }^{100}$ Mice with complete inactivation of peroxisomal $\beta$-oxidation at the level of second enzyme, exhibit severe growth retardation and postnatal mortality with none surviving beyond weaning. $\mathrm{L}-\mathrm{PBE}^{-1-} / \mathrm{D}^{-} \mathrm{PBE}^{-1-}$ mice that survived exceptionally beyond the age of 3 weeks exhibited overexpression of PPAR $\alpha$-regulated genes in liver, despite the absence of morphological evidence of hepatic peroxisome proliferation. These double null mice show that complete disruption of $\beta$-oxidation at the level of second enzyme results in induction of many of PPAR $\alpha$ target genes independently of hepatic peroxisome proliferation suggesting that intermediate metabolites of very long-chain fatty acids and other substrates of peroxisomal $\beta$-oxidation act as ligands for PPAR $\alpha$. This L-PBE ${ }^{-1-} / \mathrm{D}-\mathrm{PBE}^{-1-}$ mouse model also shows that hyperinducible L-PBE, and to some extent D-PBE, contribute to the morphological entity of peroxisome proliferation. ${ }^{100}$

Overall, these mouse knockout models point to the criticality of PPAR $\alpha$-inducible fatty acid oxidation systems in energy metabolism and in the development of hepatic steatosis. These model systems also suggest that main- 


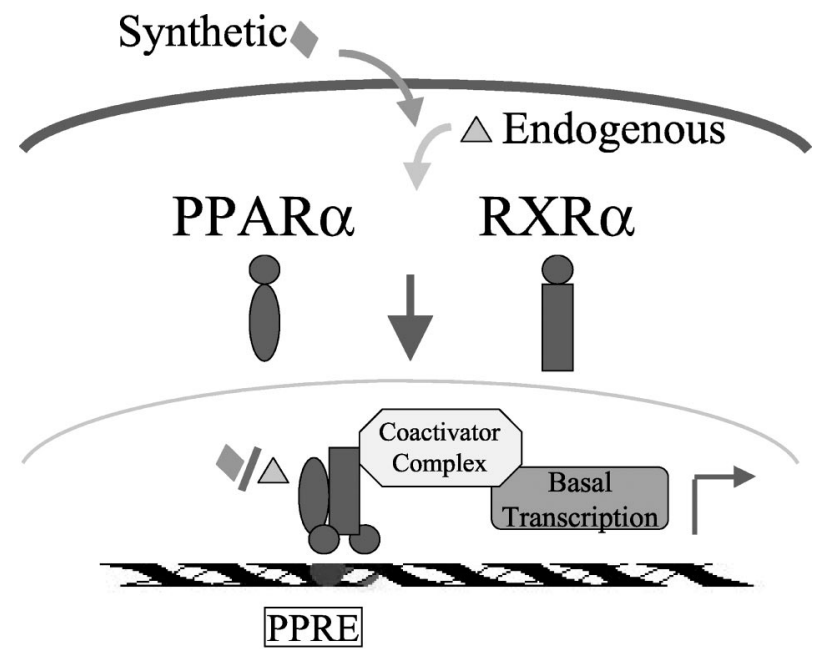

Figure 13. Model for the involvement of nuclear receptor coactivators in PPAR $\alpha$ mediated transcription (reproduced with permission from reference 46).

tenance of high levels of fatty acid oxidation reduced fat accumulation in liver and in extrahepatic tissues.

\section{PPAR-Interacting Nuclear Receptor Coactivators}

During the past decade, we focused our attention on the mechanisms underlying the transcriptional activation of PPARs in an effort to understand the basis for the gene-, tissue/cell- and species-specific transcriptional activation. Transcriptional activity of PPARs and other nuclear receptors is regulated by the binding of specific ligands and by the orchestrated recruitment and assembly of several cofactors that assemble into multi-subunit protein coactivator complexes on promoters. ${ }^{14-116}$ These coactivator proteins activate the AF-2 domain of the nuclear receptor and enhance transcription by linking the liganded nuclear receptor to the basal transcription machinery (Figure 13). After the initial cloning of SRC-1, ${ }^{117-119}$ two other members of this SRC-1/p160 family of coactivators, TIF2/GRIP1/ SRC-2 ${ }^{120,121}$ and ACTR/pCIP/AIB1/SRC-3, ${ }^{122-124}$ were cloned and it has been demonstrated that these SRC1-/ p160 family of proteins form a multi-subunit complex with CBP/p300. ${ }^{114-116,118}$

Subsequently, using yeast two-hybrid screening and other methodologies, several nuclear receptor coactivators and coactivator binding proteins were identified. ${ }^{114-116,125-127}$ We used yeast two-hybrid screen to identify and characterize coactivators that interact with and influence PPAR-mediated transcriptional activation. We cloned SRC-1, ${ }^{119}$ PPAR binding protein (PBP), ${ }^{126}$ and PPAR-interacting protein (PRIP). ${ }^{127}$ SRC-1 contained two PPAR binding regions; one located between residues 620 and 789 displays stronger interaction with PPAR than the second binding domain located at the carboxylterminus between residues $1231-1447 .{ }^{119}$ The first region contains three LXXLL motifs and the second region contains one LXXLL motif; these LXXLL motifs in coactivators appear sufficient and necessary for the binding of the coactivators to nuclear receptors. ${ }^{122,128}$ SRC-1 en-

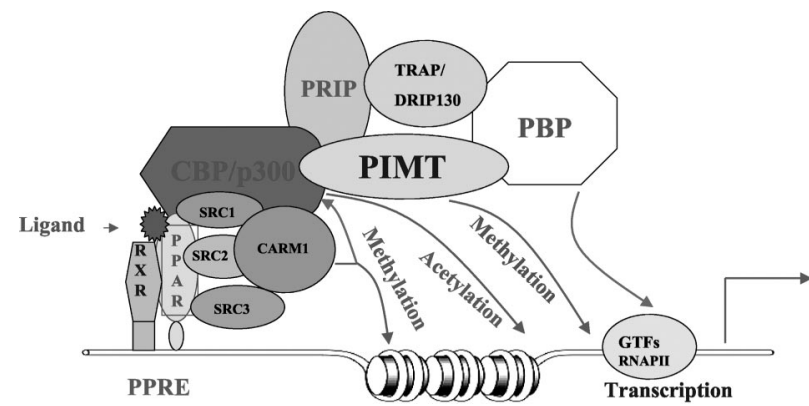

Figure 14. A proposed model for the bridging role of PIMT and PRIP in the formation of multi-subunit cofactor complex (reproduced from reference 139).

hances the transactivation function of both ligand-bound PPAR $\alpha$ and PPAR $\gamma .{ }^{119}$ A strong interaction between PPAR $\gamma$ and SRC-1 has been observed in the absence of ligand, suggesting the presence of natural PPAR ligands in the transactivation system. ${ }^{119}$ SRC-1 has a basic helixloop-helix (bHLH) motif indicating that it can function as a transcription factor by itself. ${ }^{119}$ The PBP we cloned, using PPAR $\gamma$ as bait, is not a member of SRC1/p160 family. ${ }^{126}$ PBP contains two LXXLL motifs and it binds to PPAR $\gamma$, PPAR $\alpha$, RXR, RAR, TR $\beta 1$, and ER. ${ }^{126}$ The binding site for PBP on PPAR is located to the extreme carboxyl-terminal region of the ligand binding domain and deletion of last 12 amino acids from the PPAR $\gamma$ results in the abolition of interaction between PBP and PPAR $\gamma .{ }^{126}$ Subsequently, PBP was identified as TRAP220, the anchor protein for TRAP complex. ${ }^{129}$ PBP/TRAP220 gene is amplified and overexpressed in several breast cancers suggesting that it might enhance the transcriptional activity of ER and other transcription factors important in mammary growth control and differentiation. ${ }^{130}$ We recently showed that PBP has 6 phosphorylation sites including two extracellular signalregulated kinase 2 sites of the mitogen-activated protein kinase (MAPK) family at threonine 1017 and threonine 1444. ${ }^{131}$ PBP phosphorylation by Raf/MEK/MAPK cascade exerts positive effect on PBP coactivator function. ${ }^{131}$ We also cloned another PPAR-interacting coactivator designated PRIP/ASC2/RAP250/NRC/TRBP 127,132-135 and PRIP binding protein PIMT. ${ }^{136}$ PRIP interacts with PPARs and several nuclear receptors. ${ }^{127,132-135}$ It is of interest that it binds CBP/p300 and the TRAP130 of the TRAP/DRIP/ ARC complex. ${ }^{129,137,138}$ Thus, PRIP appears to function as a bridge between the first coactivator complex anchored by CBP/p300 and the downstream TRAP/DRIP/ ARC mediator complex anchored by PBP. Furthermore, PRIP interacting protein PIMT forms a complex with CBP/ p300 and PBP. ${ }^{133,135,139}$ These findings further attest to the possibility that the two multi-protein coactivator complexes merge into one megacomplex on DNA template (Figure 14). Consistent with this is the isolation of a transcriptionally active PPAR $\alpha$-interacting cofactor (PRIC) complex from rat liver nuclear extracts. ${ }^{87}$ PRIC complex from rat liver nuclear extracts, which has been isolated using full-length PPAR $\alpha$ in the presence of ciprofibrate, a synthetic ligand, and leukotriene $\mathrm{B}_{4}$, a natural ligand, comprises some $\sim 25$ polypeptides. PRIC complex provides a snapshot of aggregation of cofactors on liganded 
GST-PPAR $\alpha$ matrix but does not provide the dynamics of assembly of association and dissociation of cofactors. PRIC complex includes known coactivators and coactivator binding proteins and other known and unknown proteins that have not previously been described in association with transcription complexes. ${ }^{87}$ One of these proteins, PRIC285, contains five LXXLL motifs and interacts with PPAR $\alpha$, PPAR $\gamma, \operatorname{ER} \alpha, \operatorname{RXR}$ and TR $\beta 1 .{ }^{87}$ There are few other polypeptides in PRIC complex with LXXLL motifs that require further characterization.

\section{PRIP Binding Protein PIMT}

Coactivator-associated enhancement of transcription involves recruitment of coactivator-associated proteins such as coactivator-associated arginine methyltransferase 1 (CARM1), a member of the S-adenosyl-L-methionine-dependent protein arginine methyltransferase family. ${ }^{140}$ CARM1 catalyzes the methylation of arginine residues in histone and thus is known to enhance the function of the SRC-1/p160 family of coactivators. ${ }^{140}$ Another coactivator-associated protein PIMT, which exhibits RNA binding and methyltransferase properties, ${ }^{136}$ has been shown to interact with CBP, p300, and PBP. ${ }^{139}$ PIMT is evolutionarily highly conserved. ${ }^{136,141,142}$ Yeast homologue of PIMT, designated Tgs1p, appears essential for hypermethylation of the $\mathrm{m} 7 \mathrm{G}$ caps of both snRNAs and snoRNAs. ${ }^{141}$ Additional studies are required to determine the role of this RNA methyltransferase in nuclear receptor-mediated transcription.

\section{Coactivator Gene Knockout Mouse Models}

We and others have initiated gene disruption studies to evaluate the biological functions of nuclear receptor coactivators. ${ }^{143-154}$ SRC-1, TIF/GRIP1/SRC-2, and p/CIP/ SRC-3 null mice are viable but show varying degrees of developmental reproductive functional perturbations and partial hormone resistance. ${ }^{143-147}$ SRC-1 mice fed PPAR $\alpha$ ligands responded in a fashion similar to that exhibited by wild-type mice fed the drug, suggesting that SRC- 1 is redundant for PPAR $\alpha$ transcriptional activity. ${ }^{144}$ The hepatic responses of SRC-1 null mice to other nuclear receptor ligands remain to be determined. In contrast to SRC-1/p160 family of coactivators, PBP and PRIP null mutations revealed embryonic lethality. ${ }^{148-155} \mathrm{PBP} /$ TRAP220 is critical for the development of placenta and for the normal embryonic development of the heart, eye, vascular, and hematopoietic systems. ${ }^{148,150,151}$ PBP null embryos died around embryonic day 11.5 with cardiac failure due to noncompaction of myocardium. ${ }^{150}$ Phenotypic changes in four organ systems noted in PBP null mice overlapped with those in mice deficient in members of GATA, a family of transcription factors known to regulate differentiation of megakaryocytes, erythrocytes, and adipocytes. ${ }^{150}$ PBP also interacts with GATA factors and this interaction is not dependent on LXXLL motifs. ${ }^{150}$ PRIP null mutation also resulted in embryonic lethality between E11.5 and E12.5 with abnormalities in the development of placenta, heart, liver, and generalized growth retardation. ${ }^{152-154}$ Livers in PRIP null embryos revealed marked apoptosis. ${ }^{152}$ Mouse embryonic fibroblasts derived from PRIP null embryos failed to exhibit PPAR $\gamma$-mediated adipogenesis. ${ }^{155}$ Based on available data from gene knockout studies, coactivators fall into the essential (nonredundant) and nonessential (redundant) categories from the developmental considerations. Additional studies using tissue-specific conditional knockouts should provide valuable information regarding the role of these essential coactivators in specific nuclear receptor function. In this regard, it is of interest to note that PBP gene-disrupted hepatocytes in PBP liver conditional null mice fail to respond to peroxisome proliferators implying that neither PPAR $\alpha$ nor PBP alone is sufficient for the transcriptional activation of PPAR $\alpha$ target genes in liver. ${ }^{156}$

In summary, our work has provided a platform to investigate the cellular and molecular mechanisms responsible for the induction of peroxisomes and peroxisomal enzymes in response to a novel class of structurally diverse xenobiotic chemicals. The studies also defined and delineated the consequences of sustained induction of enzymes associated with peroxisome proliferation. These observations laid the foundations for a xenobiotic receptor-mediated mechanism and also proposed the concept early on that reactive oxygen species and oxidative stress can contribute to carcinogenesis. The gene knockout model systems should enable further studies on the role of fatty acid oxidation and fatty acid metabolic intermediates in PPAR $\alpha$ gene transcription and in nuclear receptor coactivator function.

\section{Acknowledgments}

This work represents the efforts of many colleagues, including graduate students, postdoctoral fellows, and faculty to whom I am immensely grateful. I thank Drs. M. Sambasiva Rao, Takashi Hashimoto, Nobuteru Usuda, Narendra Lalwani, Yijun Zhu, Chao Qi, Sailesh Surapureddi, Yuzhi Jia, and Anjana Yeldandi who contributed greatly to this work. I thank the National Institute of General Medical Sciences and the National Cancer Institute, National Institutes of Health, for their support of this research. I thank Drs. Nobuteru Usuda and Yuzhi Jia for the illustrative materials. I also thank Ms. Nancy Starks for excellent secretarial assistance.

\section{References}

1. Hess R, Staubli W, Riess W: Nature of the hepatomegalic effect of produced by ethyl-chlorophenoxy-isobutyrate in the rat. Nature 1965, 208:856-858

2. Svoboda D, Azarnoff DL: Response of hepatic microbodies to a hypolipidemic agent, ethyl chlorophenoxyisobutyrate (CPIB). J Cell Biol 1966, 30:442-450

3. Svoboda D, Azarnoff D, Reddy J: Microbodies in experimentally altered cells. II. The relationship of microbody proliferation to endocrine glands. J Cell Biol 1969, 40:734-746

4. Reddy J, Bunyaratvej S, Svoboda D: Microbodies in experimentally altered cells. IV. Acatalasemic $\left(\mathrm{CS}^{\mathrm{b}}\right)$ mice treated with CPIB. J Cell Biol 1969, 42:587-596

5. Reddy J, Chiga M, Bunyaratvej S, Svoboda D: Microbodies in experimentally altered cells. VII. CPIB- induced hepatic microbody 
proliferation in the absence of significant catalase synthesis. J Cell Biol 1970, 44:226-234

6. Reddy JK: Possible properties of microbodies (peroxisomes): microbody proliferation and hypolipidemic drugs. J Histochem Cytochem 1973, 21:967-971

7. Reddy JK, Azarnoff DL, Svoboda DJ, Prasad JD: Nafenopin-induced hepatic microbody (peroxisome) proliferation and catalase synthesis in rats and mice: absence of sex difference in response. J Cell Biol 1974, 61:344-358

8. Reddy JK: Hepatic microbody proliferation and catalase synthesis induced by methyl clofenapate, a hypolipidemic analog of CPIB. Am J Pathol 1974, 75:103-118

9. Reddy JK, Krishnakantha TP: Hepatic peroxisome proliferation: induction by two novel compounds structurally unrelated to clofibrate. Science 1975, 190:787-789

10. Lazarow PB, De Duve C: A fatty acyl-CoA oxidizing system in rat liver peroxisomes: enhancement by clofibrate, a hypolipidemic drug. Proc Natl Acad Sci USA 1976, 73:2043-2046

11. Reddy JK, Rao MS, Moody DE: Hepatocellular carcinoma in acatalasemic mice treated with nafenopin, a hypolipidemic peroxisome proliferator. Cancer Res 1976, 36:1211-1217

12. Reddy JK, Rao MS: Malignant tumors in rats fed nafenopin, a hepatic peroxisome proliferator. J Natl Cancer Inst 1977, 59:16451650

13. Reddy JK, Rao MS, Azarnoff DL, Sell S: Mitogenic and carcinogenic effects of a hypolipidemic peroxisome proliferator, [4-chloro-6-(2, 3-xylidino)-2-pyrimidinylthio] acetic acid (Wy-14,643) in rat and mouse liver. Cancer Res 1979, 39:152-161

14. Reddy JK, Qureshi SA: Tumorigenicity of the hypolipidaemic peroxisome proliferator ethyl- $\alpha$-p chlorophenoxyisobutyrate (clofibrate) in rats. Br J Cancer 1979, 40:476-482

15. Reddy JK, Azarnoff DL, Hignite CE: Hypolipidaemic hepatic peroxisome proliferators form a novel class of chemical carcinogens. Nature 1980, 283:397-398

16. Warren JR, Simmon VF, Reddy JK: Properties of hypolipidemic peroxisome proliferators in the lymphocyte $\left({ }^{3} \mathrm{H}\right)$ thymidine and Salmonella mutagenesis assays. Cancer Res 1980, 40:36-41

17. Reddy JK, Lalwani ND: Carcinogenesis by hepatic peroxisome proliferators: evaluation of the risk of hypolipidemic drugs and industrial plasticizers to humans. CRC Crit Rev Toxicol 1983, 12:1-58

18. Reddy JK, Rao MS: Peroxisome proliferators and cancer: mechanisms and implications. Trends Pharmacol Sci 1986, 7:438-443

19. Rao MS, Reddy JK: Peroxisome proliferation and hepatocarcinogenesis. Carcinogenesis 1987, 8:631-636

20. Reddy JK, Lalwani ND, Reddy MK, Qureshi SA: Excessive accumulation of autofluorescent lipofuscin in the liver during hepatocarcinogenesis by methyl clofenapate and other hypolipidemic peroxisome proliferators. Cancer Res 1982, 42:259-266

21. Rao MS, Lalwani ND, Watanabe TK, Reddy JK: Inhibitory effect of antioxidants ethoxyquin and (2(3)-tert-butyl-4-hydroxyanisole on hepatic tumorigenesis in rats fed ciprofibrate, a peroxisome proliferator. Cancer Res 1984, 44:1072-1076

22. Fahl WE, Lalwani ND, Watanabe T, Goel SK, Reddy JK: DNA damage related to increased hydrogen peroxide generation by hypolipidemic drug-induced liver peroxisomes. Proc Natl Acad Sci USA 1984, 81:7827-7830

23. Goel SK, Lalwani ND, Reddy JK: Peroxisome proliferation and lipid peroxidation in rat liver. Cancer Res 1986, 46:1324-1331

24. Reddy JK, Goel SK, Nemali MR, Carrino JJ, Laffler TG, Reddy MK, Sperbeck SJ, Osumi T, Hashimoto T, Lalwani ND, Rao MS: Transcription regulation of peroxisomal fatty acyl-CoA oxidase and enoyl-CoA hydratase/3-hydroxyacyl-CoA dehydrogenase in rat liver by peroxisome proliferators. Proc Natl Acad Sci USA 1986, 83:17471751

25. Reddy JK: Carcinogenicity of peroxisome proliferators: evaluation and mechanisms. Biochem Soc Trans 1990, 18:92-94

26. Issemann I, Green S: Activation of a member of the steroid hormone receptor superfamily by peroxisome proliferators. Nature 1990, 347: 645-650

27. Dreyer C, Krey G, Keller H, Givel F, Helftenbein G, Wahli W: Control of the peroxisomal $\beta$-oxidation pathway by a novel family of nuclear hormone receptors. Cell 1992, 68:879-887

28. Rhodin $\mathrm{J}$ : Correlation of ultrastructural organization and function in normal and experimentally changed proximal convoluted tubule cells of the mouse kidney. Aktiebolaget Godvil, Stockholm, 1954

29. De Duve C: Functions of microbodies (peroxisomes). J Cell Biol 1965, 27:25A-26A

30. De Duve C: The peroxisome in retrospect. Ann NY Acad Sci 1996, 804:1-10

31. Rouiller C, Bernhard W: "Microbodies" and the problem of mitochondrial regeneration in liver cells. J Biophys Biochem Cytol Suppl 1956, 2:355-359

32. De Duve C, Baudhuin P: Peroxisomes (microbodies and related particles). Physiol Rev 1966, 46:323-357

33. Muller M, Hogg JF, De Duve C: Distribution of tricarboxylic acid cycle enzymes and glyoxylate cycle enzymes between mitochondria and peroxisomes in Tetrahymena pyriformis. J Biol Chem 1968, 243:5385-5395

34. Novikoff AB, Goldfischer S: Visualization of peroxisomes (microbodies) and mitochondria with diaminobenzidine. J Histochem Cytochem 1969, 17:675-680

35. Hruban Z, Vigil EL, Slesers A, Hopkins E: Microbodies: constituent organelles of animal cells. Lab Invest 1972, 27:184-191

36. Reddy J, Svoboda D: Microsomes (peroxisomes) in the interstitial cells of rodent testis. Lab Invest 1972, 26:657-665

37. Reddy J, Svoboda D: Microbodies in Leydig cell tumors of rat testis J Histochem Cytochem 1972, 20:793-804

38. Bendayan M, Reddy JK: Immunocytochemical localization of catalase and heat-labile enoyl-CoA hydratase in the livers of normal and peroxisome proliferator-treated rats. Lab Invest 1982, 47:364-369

39. von den Bosch H, Schutgens RB, Wanders RJ, Tager JM: Biochemistry of peroxisomes. Annu Rev Biochem 1992, 61:157-197

40. Usuda N, Reddy MK, Hashimoto T, Rao MS, Reddy JK: Tissue specificity and species differences in the distribution of urate oxidase in peroxisomes. Lab Invest 1988, 58:100-111

41. Reddy PG, Nemali MR, Reddy MK, Reddy MN, Yuan PM, Yuen S, Laffler TG, Shiroza T, Kuramitsu HK, Usuda N, Chisholm RL, Rao MS, Reddy JK: Isolation and sequence determination of a CDNA clone for rat peroxisomal urate oxidase: liver-specific expression in the rat. Proc Natl Acad Sci USA 1988, 85:9081-9085

42. Alvares K, Widrow RJ, Abu-Jawdeh GM, Schmidt JV, Yeldandi AV, Rao MS, Reddy J: Rat urate oxidase produced by recombinant baculovirus expression; formation of peroxisome crystalloid corelike structures. Proc Natl Acad Sci USA 1992, 89:4908-4912

43. Yeldandi AV, Chu R, Reddy SK, Pan J, Usuda N, Lin Y, Rao MS, Reddy JK: Functional expression and peroxisomal targeting of rat urate oxidase in monkey kidney cells. Gene Express 1995, 5:125132

44. Yeldandi AV, Yeldandi V, Kumar S, Murthy CV, Wang XD, Alvares K, Rao MS, Reddy JK: Molecular evolution of the urate oxidase-encoding gene in hominoid primates: nonsense mutations. Gene 1991, 109:281-284

45. Wu XW, Lee CC, Muzny DM, Caskey CT: Urate oxidase: primary structure and evolutionary implications. Proc Natl Acad Sci USA 1989, 86:9412-9416

46. Reddy JK, Hashimoto T: Peroxisomal $\beta$-oxidation and peroxisome proliferator-activated receptor $\alpha$ : an adaptive metabolic system. Ann Rev Nutr 2001, 21:193-230

47. Azarnoff DL, Reddy JK, Hignite C, Fitzgerald T: Structure activity relationship of clofibrate-like compounds on lipid metabolism. Proc 6th Int Congr Pharmacol 1975, 4:137-147

48. Moody DE, Reddy JK: Hepatic peroxisome (microbody) proliferation in rats fed plasticizers and related compounds. Toxic Appl Pharamcol 1978, 45:497-504

49. Lalwani ND, Reddy MK, Qureshi SA, Sirtori CR, Abiko Y, Reddy JK: Evaluation of selected hypolipidemic agents for the induction of peroxisomal enzymes and peroxisome proliferation in rat liver. Hum Toxicol 1983, 2:27-48

50. Reddy JK, Chu R: Peroxisome proliferator-induced pleiotropic responses: pursuit of a phenomenon. Peroxisomes: Biology and Role in Toxicology and Disease. Edited by Reddy JK, Suga T, Mannaerts G, Lazarow P, Subramani S. Ann NY Acad Sci 1996 804:176-201

51. Moody DE, Rao MS, Reddy JK: Mitogenic effect in mouse liver induced by a hypolipidemic drug, nafenopin. Virchows Arch B Cell Pathol 1977, 23:291-296

52. Moody DE, Reddy JK: Morphometric analysis of the ultrastructural 
changes in rat liver induced by the peroxisome proliferator, $\mathrm{SaH}$ 42-348. J Cell Biol 1976, 71:768-780

53. Watanabe T, Lalwani ND, Reddy JK: Specific changes in the protein composition of rat liver in response to the peroxisome proliferators ciprofibrate, Wy-14,643 and di-(2-ethylhexyl)phthalate. Biochem $J$ 1985, 227:767-775

54. Chu R, Lim H, Brumfield L, Liu H, Herring C, Ulintz P, Reddy JK, Davison M: Protein profiling of mouse livers with peroxisome proliferator-activated receptor $\alpha$ activation. Mol Cell Biol 2004, in press

55. Nemali MR, Usuda N, Reddy MK, Oyasu K, Hashimoto T, Osumi T, Rao MS, Reddy JK: Comparison of constitutive and inducible levels of expression of peroxisomal $\beta$-oxidation and catalase genes in liver and extrahepatic tissues of rat. Cancer Res 1988, 48:5316-5324

56. Ashby J, Brady A, Elcombe CR, Elliott BM, Ishmael J, Odum J, Tugwood JD, Kettle S, Purchase IF: Mechanistically based human hazard assessment of peroxisome proliferator-induced hepatocarcinogenesis. Human Exp Toxicol 1994, 13(Suppl 2):S1-117

57. Kluwe WM, McConnell EE, Huff JE, Haseman JK, Douglas JF, Hartwell WV: Carcinogenicity testing of phthalate esters and related compounds by the National Toxicology Program and the National Cancer Institute. Environ Health Perspect 1982, 45:129-133

58. David RM, Moore MR, Cifone MA, Finney DC, Guest D: Chronic peroxisome proliferation and hepatomegaly associated with the hepatocellular tumorigenesis of di(2-ethylhexyl)phthalate and the effects of recovery. Toxicol Sci 1999, 50:195-205

59. Weisburger JH, Williams GM: The distinction between genotoxic and epigenetic carcinogens and implication for cancer risk. Toxicol Sci 2000, $57: 4-5$

60. Glauert HP, Reddy JK, Kennan WS, Sattler GL, Rao VS, Pitot HC: Effect of hypolipidemic peroxisome proliferators on unscheduled DNA synthesis in cultured hepatocytes and on mutagenesis in Salmonella. Cancer Lett 1984, 24:147-156

61. Schiestl RH, Reddy JK: Effect of peroxisome proliferators on intrachromosomal and interchromosomal recombination in yeast. Carcinogenesis 1990, 11:173-176

62. Gupta RC, Goel SK, Earley K, Singh B, Reddy JK: ${ }^{32}$ P-post-labeling analysis of peroxisome proliferator-DNA adduct formation in rat liver in vivo and hepatocytes in vitro. Carcinogenesis 1985, 6:933-936

63. Randerath E, Randerath K, Reddy R, Danna TF, Rao MS, Reddy JK: Induction of rat liver DNA alterations by chronic administration of peroxisome proliferators as detected by ${ }^{32} \mathrm{P}$ post-labeling. Mutat Res 1991, 247:65-76

64. Rao MS, Lalwani ND, Scarpelli DG, Reddy JK: The absence of $\gamma$-glutamyltranspeptidase activity in putative preneoplastic lesions and in hepatocellular carcinomas induced in rats by the hypolipidemic peroxisome proliferator Wy-14, 643. Carcinogenesis 1982, 3:1231-1233

65. Rao MS, Reddy JK: Hepatocarcinogenesis of peroxisome proliferators. Ann NY Acad Sci 1996, 804:573-587

66. Meyer K, Lee J-S, Dyck PA, Cao WQ, Rao MS, Thorgeirsson SS, Reddy JK: Molecular profiling of hepatocellular carcinomas developing spontaneously in acyl-CoA oxidase deficient mice: comparison with liver tumors induced in wild-type mice by a peroxisome proliferator and a genotoxic carcinogen. Carcinogenesis 2003, 24: 975-984

67. Yeldandi AV, Rao MS, Reddy JK: Hydrogen peroxide generation in peroxisome proliferator-induced oncogenesis. Mutat Res 2000, 448: 159-177

68. Giometti CS, Liang X, Tollaksen SL, Wall DB, Lubman DM, Subbarao $\mathrm{V}$, Rao MS: Mouse liver selenium binding protein decreased in abundance by peroxisome proliferators. Electrophoresis 2000, 21: 2162-2169

69. Kasai H, Okada Y, Nishimura S, Rao MS, Reddy JK: Formation of 8-hydroxydeoxyguanosine in liver DNA of rats following long-term exposure to a peroxisome proliferator. Cancer Res 1989, 49:26032605

70. Rusyn I, Asakura S, Pachkowski B, Bradford BU, Denissenko MF, Peters JM, Holland SM, Reddy JK, Cunningham ML, Swenberg JA: Expression of base excision DNA repair genes is a sensitive biomarker for in vivo detection of chemical-induced chronic oxidative stress: identification of the molecular source of radicals responsible for DNA damage by peroxisome proliferators. Cancer Res 2004, 64:1050-1057

71. Yeldandi AV, Milano M Subbarao V, Reddy JK, Rao MS: Evaluation of liver cell proliferation during ciprofibrate-induced hepatocarcinogenesis. Cancer Lett 1989, 47:21-27

72. Overturf K, al-Dhalimy M, Ou CN, Finegold M, Grompe M: Serial transplantation reveals the stem-cell like regenerative potential of adult mouse hepatocytes. Am J Pathol 1997, 151:1273-1280

73. Chu R, Huang Q, Alvares K, Yeldandi AV, Rao MS, Reddy JK: Transformation of mammalian cells by overexpressing $\mathrm{H}_{2} \mathrm{O}_{2}$-generating peroxisomal fatty acyl-CoA oxidase. Proc Natl Acad Sci USA 1995, 92:7080-7084

74. Okamoto M, Reddy JK, Oyasu R: Tumorigenic conversion of a nontumorigenic rat urothelial cell line by overexpression of $\mathrm{H}_{2} \mathrm{O}_{2}$ generating peroxisomal fatty acyl-CoA oxidase. Int J Cancer 1997 70:716-721

75. Dadras SS, Thorgeirsson SS, Rao MS, Reddy JK: Implication of hydrogen peroxide generation and apoptosis in the neoplastic transformation of mouse fibroblasts overexpressing peroxisomal fatty acyl-CoA oxidase. Int J Oncol 1998, 12:37-44

76. Chu R, Lin Y, Reddy KC, Pan J, Rao MS, Reddy JK, Yeldandi AV: Transformation of epithelial cells stably transfected with $\mathrm{H}_{2} \mathrm{O}_{2}$-generating peroxisomal urate oxidase. Cancer Res 1996, 56:48464852

77. Varanasi U, Chu R, Huang Q, Castellon R, Yeldandi AV, Reddy JK Identification of a peroxisome proliferator-responsive element upstream of the human peroxisomal fatty acyl coenzyme A oxidase gene. J Biol Chem 1996, 271:2147-2155, 273:30842

78. Woodyatt NJ, Lambe KG, Myers KA, Tugwood JD, Roberts RA: The peroxisome proliferator (PP) response element upstream of the human acyl-CoA oxidase gene is inactive among a sample human population: significance for species differences in response to PPs. Carcinogenesis 1999, 20:369-372

79. Lambe KG, Woodyatt NJ, Macdonald N, Chevalier S, Roberts RA Species differences in sequence and activity of the peroxisome proliferator response element (PPRE) within the acyl CoA oxidase gene promoter. Toxicol Lett 1999, 100:119-127

80. Suh YA, Arnold RS, Lassegue B, Shi J, Xu X, Sorescu D, Chung AB, Griendling KK, Lambeth JD: Cell transformation by the superoxidegenerating oxidase Mox1. Nature 1999, 401:79-82

81. Reddy JK, Jirtle RL, Watanabe TK, Reddy MK, Michalopoulos G, Qureshi SA: Response of hepatocytes transplanted into syngeneic hosts and heterotransplanted into athymic nude mice to peroxisome proliferators. Cancer Res 1984, 44:2582-2589

82. Rao MS, Thorgeirsson S, Reddy MK, Lalwani ND, Evarts RE, Usman MI, Singh B, Reddy JK: Induction of peroxisome proliferation in hepatocytes transplanted into the anterior chamber of the eye: a model system for the evaluation of xenobiotic-induced effects. Am J Pathol 1986, 124:519-527

83. Rao MS, Reddy JK: Liver stem cells in pancreas. Disease Progression and Carcinogenesis in the Gastrointestinal Tract-Falk Symposium 132. Edited by Galle PR, Gerken G, Schmidt WE, Widenmann B. United Kingdom, Kluwer, 2003, pp 11-30

84. Lalwani ND, Fahl WE, Reddy JK: Detection of a nafenopin binding protein in rat liver cytosol associated with the induction of peroxisome proliferation by hypolipidemic compounds. Biochem Biophys Res Commun 1983, 116:388-393

85. Lalwani ND, Alvares K, Reddy MK, Reddy MN, Parikh I, Reddy JK Peroxisome proliferator binding protein: identification and partia characterization of nafenopin-, clofibric acid-, and ciprofibrate binding proteins from rat liver. Proc Natl Acad Sci USA 1987, 84:51425146

86. Reddy JK, Rao MS: Peroxisome proliferation-related oxidative stress and hepatocarcinogenesis. In: Carcinogenesis and Radiation Protection. Edited by Cerutti PA, Nygaard AF, Simic MG. New York, Plenum Press, 1987, pp 85-91

87. Surapureddi S, Yu S, Bu H, Hashimoto T, Yeldandi AV, Kashireddy P, Cherkaoui-Malki M, Qi C, Zhu YJ, Rao MS, Reddy JK: Identification of a transcriptionally active peroxisome proliferator-activated receptor $\alpha$-interacting cofactor complex in rat liver and characterization of PRIC285 as a coactivator. Proc Natl Acad Sci USA 2002, 99:11836-11841

88. Chawla A, Repa JJ, Evans RM, Mangelsdorf DJ: Nuclear receptors and lipid physiology: opening the X-files. Science 2001, 294:18661870

89. Zhu Y, Alvares K, Huang Q, Rao MS, Reddy JK: Cloning of a new 
member of the peroxisome proliferator-activated receptor gene family from mouse liver. J Biol Chem 1993, 268:26817-26820

90. Tontonoz P, Hu E, Graves RA, Budavari Al, Spiegelman BM: mPPAR 2 2: tissue-specific regulator of an adipocyte enhancer. Genes Dev 1994, 8:1224-1234

91. Willson TM, Brown PJ, Sternbach DD, Henke BR: The PPARS: from orphan receptors to drug discovery. J Med Chem 2000, 43:527-550

92. Desvergne B, Wahli W: Peroxisome proliferator-activated receptors: nuclear control of metabolism. Endocr Rev 1999, 20:649-688

93. Zhu Y, Qi C, Korenberg JR, Chen X-N, Noya D, Rao MS, Reddy JK: Structural organization of mouse peroxisome proliferator-activated receptor $\gamma($ mPPAR $\gamma)$ gene: alternative promoter use and different splicing yield two mPPAR $\gamma$ isoforms. Proc Natl Acad Sci USA 1995, 92:7921-7925

94. Kliewer SA, Umesono K, Noonan DJ, Heyman RA, Evans RM: Convergence of 9-cis retinoic acid and peroxisome proliferator signaling pathways through heterodimer formation of their receptors. Nature 1992, 358:771-774

95. Gottlicher M, Widmark E, Li Q, Gustafsson JA: Fatty acids activate a chimera of the clofibric acid-activated receptor and the glucocorticoid receptor. Proc Natl Acad Sci USA 1992, 89:4653-4657

96. Lee SS, Pineau T, Drago J, Lee EJ, Owens JW, Kroetz DL, Fernandez-Salguero PM, Westphal H, Gonzalez FJ: Targeted disruption of the $\alpha$ isoform of the peroxisome proliferators-activated receptor gene in mice results in abolishment of the pleiotropic effects of peroxisome proliferators. Mol Cell Biol 1995, 15:3012-3022

97. Peters JM, Cattley RC, Gonzalez FJ: Role of PPAR $\alpha$ in the mechanism of action of the nongenotoxic carcinogen and peroxisome proliferator Wy-14, 643. Carcinogenesis 1997, 18:2029-2033

98. Peters JM, Lee SS, Li W, Ward JM, Gavrilova O, Everett C, Reitman ML, Hudson LD, Gonzalez FJ: Growth, adipose, brain, and skin alterations resulting from targeted disruption of the mouse peroxisome proliferator-activated receptor $\beta / \delta$. Mol Cell Biol 2000, 20: $5119-5128$

99. Wang YX, Lee CH, Tiep S, Yu RT, Ham J, Kang H, Evans RM: Peroxisome proliferator-activated receptor $\delta$ activates fat metabolism to prevent obesity. Cell 2003, 113:159-170

100. Hashimoto T, Fujita T, Usuda N, Cook W, Qi C, Peters JM, Gonzalez FJ, Yeldandi AV, Rao MS, Reddy JK: Peroxisomal and mitochondrial fatty acid $\beta$-oxidation in mice nullizygous for both peroxisome proliferator-activated receptor $\alpha$ and peroxisomal fatty acyl-CoA oxidase: genotype correlation with fatty liver phenotype. J Biol Chem 1999, 274:19228-19236

101. Mueller E, Drori S, Aiyer A, Yie J, Sarraf P, Chen H, Hauser S, Rosen ED, Ge K, Roeder RG, Spiegelman BM: Genetic analysis of adipogenesis through peroxisome proliferator-activated receptor $\gamma$ isoforms. J Biol Chem 2002, 277:41925-41930

102. Yu S, Matsusue K, Kashireddy P, Cao WQ, Yeldandi V, Yeldandi AV, Rao MS, Gonzalez FJ, Reddy JK: Adipocyte-specific gene expression and adipogenic steatosis in the mouse liver due to peroxisome proliferator activated-receptor $\gamma 1$ (PPAR $\gamma 1$ ) overexpression. J Biol Chem 2003, 278:498-505

103. Varanasi U, Chu R, Chu S, Espinosa R, LeBeau MM, Reddy JK: Isolation of the human peroxisomal acyl-CoA oxidase gene: organization, promoter analysis, and chromosomal localization. Proc Natl Acad Sci USA 1994, 91:3107-3111

104. Yu S, Rao MS, Reddy JK: Peroxisome proliferator-activated receptors, fatty acid oxidation, steatohepatitis, and hepatocarcinogenesis. Curr Mol Med 2003, 3:561-572

105. Chu R, Lin Y, Rao MS, Reddy JK: Cooperative formation of higher order peroxisome proliferator-activated receptor and retinoid $\mathrm{X}$ receptor complexes on the peroxisome proliferator responsive element of the rat hydratase-dehydrogenase gene. J Biol Chem 1995, 50:29636-29639

106. Jia Y, Qi C, Zhang Z, Hashimoto T, Rao MS, Huyghe S, Suzuki Y, Van Veldhoven PP, Baes M, Reddy JK: Overexpression of peroxisome proliferator-activated receptor- $\alpha$ (PPAR $\alpha$ )-regulated genes in liver in the absence of peroxisome proliferation in mice deficient in both $\mathrm{L}$ and D-forms of enoyl-CoA hydratase/dehydrogenase enzymes of peroxisomal $\beta$-oxidation system. J Biol Chem 2003, 278:4723247239

107. Cherkaoui-Malki M, Meyer K, Cao W-Q, Latruffe N, Yeldandi AV, Rao MS, Bradfield CA, Reddy JK: Identification of novel peroxisome proliferator-activated receptor $\alpha$ (PPAR $\alpha)$ target genes in mouse liver using cDNA microarray analysis. Gene Express 2001, 9:291304

108. Aoyama T, Peters JM, Iritani N, Nakajima T, Furihata K, Hashimoto T, Gonzalez FJ: Altered constitutive expression of fatty acid-metabolizing enzymes in mice lacking the peroxisome proliferator-activated receptor $\alpha$ (PPAR $\alpha$ ). J Biol Chem 1998, 273:5678-5684

109. Wanders RJ, Vreken P, Ferdinandusse S, Jansen GA, Waterham HR, Van Roermund CWT, Van Grunsven EG: Peroxisomal fatty acid $\alpha$ - and $\beta$-oxidation in humans: enzymology, peroxisomal metabolite transporters, and peroxisomal diseases. Biochem Soc Trans 2001, 29:250-267

110. Fan C-Y, Pan J, Chu R, Lee D, Kluckman KD, Usuda N, Singh I, Yeldandi AV, Rao MS, Maeda N, Reddy JK: Hepatocellular and hepatic peroxisomal alterations in mice with a disrupted peroxisomal fatty acyl-coenzyme A oxidase gene. J Biol Chem 1996, 271 24698-24710

111. Qi C, Zhu Y, Pan J, Usuda N, Maeda N, Yeldandi AV, Rao MS, Hashimoto T, Reddy JK: Absence of spontaneous peroxisome proliferation in enoyl-CoA hydratase/L-3-hydroxyacyl-CoA dehydrogenase-deficient mouse liver: further support for the role of fatty acylCoA oxidase in PPAR $\alpha$ ligand metabolism. J Biol Chem 1999, 274 15775-15780

112. Fan C-Y, Pan J, Usuda N, Yeldandi AV, Rao MS, Reddy JK: Steatohepatitis, spontaneous peroxisome proliferation and liver tumors in mice lacking peroxisomal fatty acyl-CoA oxidase: implications for peroxisome proliferators activated receptor $\alpha$ natural ligand metabolism. J Biol Chem 1998, 273:15639-15645

113. Hashimoto T, Cook WS, Qi C, Yeldandi AV, Reddy JK, Rao MS: Defect in peroxisome proliferator-activated receptor $\alpha$ inducible fatty acid oxidation determines the severity of hepatic steatosis in response to fasting. J Biol Chem 2000, 275:28918-28928

114. Glass CK, Rosenfeld MG: The coregulator exchange in transcriptional functions of nuclear receptors. Genes Dev 2000, 14:121-141

115. McKenna NJ, O'Malley BW: Combinatorial control of gene expression by nuclear receptors and coregulators. Cell 2002, 108:465-474

116. Lewis BA, Reinberg D: The mediator coactivator complex: functional and physical roles in transcriptional regulation. J Cell Sci 2003 116:3667-3675

117. Onate SA, Tsai SY, Tsai MJ, O'Malley BW: Sequence and characterization of a coactivator for the steroid hormone receptor superfamily. Science 1995, 270:1354-1357

118. Kamei Y, Xu L, Heinzel T, Torchia J, Kurokawa R, Gloss B, Lin SC, Heyman RA, Rose DW, Glass CK, Rosenfeld MG: A CBP integrator complex mediates transcriptional activation and AP-1 inhibition by nuclear receptors. Cell 1996, 85:403-415

119. Zhu Y, Qi C, Calandra C, Rao MS, Reddy JK: Cloning and identification of mouse steroid receptor coactivator-1 (mSRC-1), as a coactivator of peroxisome proliferator-activated receptor $\gamma$. Gene Express 1996, 6:185-195

120. Voegel JJ, Heine MJ, Zechel C, Chambon P, Gronemeyer H: TIF2, a $160 \mathrm{kDa}$ transcriptional mediator for the ligand dependent activation function AF-2 of nuclear receptors. EMBO J 1996, 15:3667-3675

121. Hong H, Kohli K, Garabedian MJ, Stallcup MR: GRIP1, a transcriptional coactivator for the AF-2 transctivation domain of steroid, thyroid, retinoid, and vitamin D receptors. Mol Cell Biol 1997, 17:27352744

122. Torchia J, Rose DW, Inostroza J, Kamei Y, Westin S, Glass CK, Rosenfeld MG: The transcriptional co-activator p/CIP binds CBP and mediates nuclear receptor function. Nature 1997, 387:677-684

123. Anzick SL, Kononen J, Walker RL, Azorsa DO, Tanner MM, Guan XY, Sauter G, Kallioniemi OP, Trent JM, Meltzer PS: AIB1, a steroid receptor coactivator amplified in breast and ovarian cancer. Science 1997, 277:965-968

124. Chen H, Lin RJ, Schiltz RL, Chakravarti D, Nash A, Nagy L, Privalsky ML, Nakatani Y, Evans RM: Nuclear receptor coactivator ACTR is a novel histone acetyltransferase and forms a multimeric activation complex with P/CAF and CBP/p300. Cell 1997, 90:569-580

125. Puigserver P, Wu Z, Park CW, Graves R, Wright M, Spiegelman FM: A cold-inducible coactivator of nuclear receptors linked to adaptive thermogenesis. Cell 1998, 92:829-839

126. Zhu Y, Qi C, Jain S, Rao MS, Reddy JK: Isolation and characterization of PBP, a protein that interacts with peroxisome proliferatoractivated receptor. J Biol Chem 1997, 272:25500-25506

127. Zhu Y, Kan L, Qi C, Kanwar YS, Yeldandi AV, Rao MS, Reddy JK: 
Isolation and characterization of peroxisome proliferator-activated receptor (PPAR) interacting protein (PRIP) as a coactivator for PPAR. J Biol Chem 2000, 275:13510-13516

128. Heery DM, Kalkhoven E, Hoare S, Parker MG: A signature motif in transcriptional co-activators mediates binding to nuclear receptors. Nature 1997, 387:733-736

129. Yuan CX, Ito M, Fondell JD, Fu ZY, Roeder RG: The TRAP220 component of a thyroid hormone receptor-associated protein (TRAP) coactivator complex interacts directly with nuclear receptors in a ligand-dependent fashion. Proc Natl Acad Sci USA 1998, 95: 7939-7944

130. Zhu Y, Qi C, Jain S, Le Beau MM, Espinosa III R, Atkins GB, Lazar MA, Yeldandi AV, Rao MS, Reddy JK: Amplification and overexpression of peroxisome proliferator-activated receptor binding protein (PBP/PPARBP) gene in breast cancer. Proc Natl Acad Sci USA 1999, 96:10848-10853

131. Misra P, Owuor ED, Li W, Yu S, Qi C, Meyer K, Zhu YJ, Rao MS, Kong AN, Reddy JK: Phosphorylation of transcriptional coactivator peroxisome proliferators-activated receptor (PPAR) binding protein (PBP): stimulation of transcriptional regulation by mitogen-activated protein kinase. J Biol Chem 2002, 277:48745-48754

132. Lee SK, Anzick SL, Choi JE, Bubendorf L, Guan XY, Jung YR, Kallioniemi OP, Kononen J, Trent JM, Azorsa D, Jhun BH, Cheong $\mathrm{JH}$, Lee YC, Meltzer PS, Lee JW: A nuclear factor, ASC-2, is a cancer-amplified transcriptional coactivators essential for liganddependent transactivation by nuclear receptors in vivo. J Biol Chem 1999, 274:34283-34293

133. Mahajan MA, Samuels HH: A new family of nuclear receptor coregulators that integrate nuclear receptor signaling through CREB binding protein. Mol Cell Biol 2000, 20:5048-5063

134. Caira F, Antonson P, Pelto-Huikko M, Treuter E, Gustafsson JA: Cloning and characterization of RAP250, a novel nuclear receptor coactivators. J Biol Chem 2000, 275:5308-5317

135. Ko L, Cardona GR, Chin WW: Thyroid hormone receptor binding protein an LXXLL motif-containing protein, functions as a general coactivator. Proc Natl Acad Sci USA 2000, 97:6212-6217

136. Zhu Y, Qi C, Cao W-Q, Yeldandi AV, Rao MS, Reddy JK: Cloning and characterization of PIMT, a protein with methyltransferase domain, which interacts with and enhances nuclear receptor coactivator PRIP function. Proc Natl Acad Sci USA 2001, 98:10380-10385

137. Rachez C, Lemon BD, Suldan Z, Bromleigh V, Gamble M, Naar AM, Erdjument-Bromage $\mathrm{H}$, Tempst P, Freedman LP: Ligand-dependent transcription activation by nuclear receptors requires the DRIP complex. Nature 1999, 398:824-828

138. Ryu S, Zhou S, Ladurner AG, Tjian R: The transcriptional cofactor complex CRSP is required for activity of the enhancer binding protein Spl. Nature 1999, 397:446-450

139. Misra P, Qi C, Yu S, Shah SH, Cao W-Q, Rao MS, Thimmapaya B, Zhu Y, Reddy JK: Interaction of PIMT with transcription coactivators $\mathrm{CBP}, \mathrm{p} 300$, and PBP differential role in transcriptional regulation. J Biol Chem 2002, 277:20011-20019

140. Chen D, Ma H, Hong H, Koh SS, Huang SM, Schurter BT, Aswad DW, Stallcup MR: Regulation of transcription by a protein methyltransferase. Science 1999, 284:2174-2177

141. Mouaikel J, Verheggen C, Bertrand E, Tazi J, Bordonne R: Hypermethylation of the cap structure of both yeast snRNAs and snoRNAs requires a conserved methyltransferase that is localized to the nucleolus. Molec Cell 2002, 9:891-901

142. Enunlu I, Papai G, Cserpan I, Udvardy A, Jeang KT, Boros I: Different isoforms of PRIP-interacting protein with methyltransferase domain/trimethylguanosine synthase localizes to the cytoplasm and nucleus. Biochem Biophys Res Commun 2003, 309:44-51
143. Xu J, Qiu Y, DeMayo FJ, Tsai SY, Tsai MJ, O'Malley BW: Partial hormone resistance in mice with disruption of the steroid receptor coactivator-1 (SRC-1) gene. Science 1998, 279:1922-1925

144. Qi C, Zhu Y, Pan J, Yeldandi AV, Rao MS, Maeda N, Subbarao V, Pulikuri S, Hashimoto T, Reddy JK: Mouse steroid receptor coactivator-1 is not essential for peroxisome proliferator-activated receptor $\alpha$ - regulated gene expression. Proc Natl Acad Sci USA 1999, 96:1585-1590

145. Xu J, Liao L, Ning G, Yoshida-Komiya H, Deng C, O'Malley BW: The steroid receptor coactivator SRC-3 (p/CIP/RAC3/AIB1/ACTR/ TRAM-1) is required for normal growth, puberty, female reproductive function, and mammary gland development. Proc Natl Acad Sci USA 2000, 97:6379-6384

146. Wang Z, Rose DW, Hermanson O, Liu F, Herman T, Wu W, Szeto D, Gleiberman A, Krones A, Pratt K, Rosenfeld R, Glass CK, Rosenfeld MG: Regulation of somatic growth by the $\mathrm{p} 160$ coactivator $\mathrm{p} / \mathrm{CIP}$. Proc Natl Acad Sci USA 2000, 97:13549-13554

147. Ge'hin M, Mark M, Dennefeld C, Dierich A, Gronemeyer H, Chambon C: The function of TIF2/ GRIP1 in mouse reproduction is distinct from those of SRC-1 and p/CIP. Mol Cell Biol 2002, 22:5923-5937

148. Zhu Y, Qi C, Jia Y, Nye JS, Rao MS, Reddy JK: Deletion of PBP/ PPARBP, the gene for nuclear receptor coactivator peroxisome proliferator-activated receptor binding protein, results in embryonic lethality. J Biol Chem 2000, 275:14779-14782

149. Ito M, Yuan CX, Okano HJ, Darnell RB, Roeder RG: Involvement of the TRAP220 component of the TRAP/SMCC coactivator complex in embryonic development and thyroid hormone action. Molec Cell 2000, 5:683-693

150. Crawford SE, Qi C, Misra P, Stellmach V, Rao MS, Engel JD, Zhu Y, Reddy JK: Defects of the heart, eye, and megakaryocytes, in peroxisome proliferator activator receptor binding protein (PBP) null embryos implicate GATA family of transcription factors. J Biol Chem 2001, 277:3585-3592

151. Landles C, Chalk S, Steel JH, Rosewell I, Spencer-Dene B, Lalani EN, Parker MG: The thyroid hormone receptor-associated protein TRAP220 is required at distinct embryonic stages in placental, cardiac, and hepatic development. Mol Endocri 2003, 17:24181435

152. Zhu YJ, Crawford SE, Stellmach V, Dwivedi RS, Rao MS, Gonzalez FJ, Qi C, Reddy JK: Coactivator PRIP, the peroxisome proliferatoractivated receptor-interacting protein, is a modulator of placental, cardiac, hepatic, and embryonic development. J Biol Chem 2003, 278:1986-1990

153. Kuang SQ, Liao L, Zhang H, Pereira FA, Yuan Y, DeMayo FJ, Ko L, $\mathrm{Xu} \mathrm{J}$ : Deletion of the cancer amplified coactivator AIB3 results in defective placentation and embryonic lethality. J Biol Chem 2002, 277:45356-45360

154. Antonson P, Schuster GU, Wang L, Rozell B, Holter E, Flodby P, Treuter E, Holmgren L, Gustafsson JA: Inactivation of the nuclear receptor coactivator RAP250 in mice results in placental vascular dysfunction. Mol Cell Biol 2003, 23:1260-1268

155. Qi C, Surapureddi S, Zhu YJ, Yu S, Kashireddy P, Rao MS, Reddy JK: Transcriptional coactivator PRIP, the peroxisome proliferatoractivated receptor $\gamma$ (PPAR $\gamma$ )-interacting protein, is required for PPAR $\gamma$-mediated adipogenesis. J Biol Chem 2003, 278:2528125284

156. Jia Y, Qi C, Kashireddy P, Surapureddi S, Zhu Y-J, Rao MS, Le Roith D, Chambon P, Gonzalez FJ, Reddy JK: Transcription coactivators PBP, the peroxisome proliferator-activated receptor (PPAR)-binding protein, is required for PPAR $\alpha$-regulated gene expression in liver. $J$ Biol Chem 2004, in press 